\title{
The role of altered immune function during the dry period in promoting the development of subclinical ketosis in early lactation
}

\author{
M. Mezzetti, ${ }^{1}$ A. Minuti, ${ }^{1}$ F. Piccioli-Cappelli, ${ }^{1}$ M. Amadori, ${ }^{2}$ M. Bionaz, ${ }^{3}$ and E. Trevisi ${ }^{1 *}$ \\ ${ }^{1}$ Department of Animal Sciences, Food and Nutrition, Faculty of Agriculture, Food and Environmental Science, \\ Università Cattolica del Sacro Cuore, 29122 Piacenza, Italy \\ ${ }^{2}$ Istituto Zooprofilattico Sperimentale della Lombardia e dell'Emilia-Romagna, Laboratory of Cellular Immunology, 25124 Brescia, Italy \\ ${ }^{3}$ Department of Animal and Rangeland Sciences, Oregon State University, Corvallis 97331
}

\begin{abstract}
Subclinical ketosis (SCK) may impair white blood cell (WBC) function and thus contribute to the risk of disease postpartum. This preliminary study investigated changes occurring in the immune system before disease onset to elucidate their role in the occurrence of SCK. A group of 13 Holstein dairy cows were housed in tiestalls and retrospectively divided into 2 groups based on their levels of $\beta$-hydroxybutyrate (BHB) measured in plasma between calving day and $35 \mathrm{~d}$ from calving (DFC). Levels of BHB $<1.4 \mathrm{mmol} / \mathrm{L}$ were found in 7 cows (control cows, CTR group) and levels $>1.4 \mathrm{mmol} / \mathrm{L}$ were found in 6 cows at $\geq 1$ of 6 time points considered (cows with SCK, KET group). From -48 to 35 DFC, body condition score, body weight, dry matter intake, rumination time, and milk yield were measured, and blood samples were collected regularly to assess the hematochemical profile and test the WBC function by ex vivo challenge assays. Data were submitted for ANOVA testing using a mixed model for repeated measurements that included health status and time and their interactions as fixed effects. Compared with CTR cows, KET cows had more pronounced activation of the immune system (higher plasma concentrations of proinflammatory cytokines, myeloperoxidase, and oxidant species, and greater IFN- $\gamma$ responses to Mycobacterium avium), higher blood concentrations of $\gamma$-glutamyl transferase, and lower plasma concentrations of minerals before calving. Higher levels of nonesterified fatty acids, BHB, and glucose were detected in KET cows than in CTR cows during the dry period. The effect observed during the dry period was associated with a reduced dry matter intake, reduced plasma glucose, and increased fat mobilization (further increases in nonesterified fatty acids and BHB) during early lactation. A reduced milk
\end{abstract}

Received February 15, 2019.

Accepted June 4, 2019.

*Corresponding author: erminio.trevisi@unicatt.it yield was also detected in KET cows compared with CTR. The KET cows had an accentuated acute-phase response after calving (with greater concentrations of positive acute-phase proteins and lower concentrations of retinol than CTR cows) and impaired liver function (higher blood concentrations of glutamate-oxaloacetate transaminase and bilirubin). The WBC of the KET cows, compared with CTR cows, had a reduced response to an ex vivo stimulation assay, with lower production of proinflammatory cytokines and greater production of lactate. These alterations in the WBC could have been driven by the combined actions of metabolites related to the mobilization of lipids and the occurrence of a transient unresponsive state against stimulation aimed at preventing excessive inflammation. The associations identified here in a small number of cows in one herd should be investigated in larger studies.

Key words: immune response, dry period, inflammation, liver function

\section{INTRODUCTION}

The transition period is a critical phase for dairy cows because of the dramatic metabolic changes that take place (Drackley, 1999). In some cases, control of the homeorhetic and homeostatic mechanisms is not effective, a situation that can lead to physiological imbalance and a substantial increase in the risk of disease (Ingvartsen and Moyes, 2013)

Ketosis is the most prevalent metabolic disease postpartum and it has a significant economic impact on the dairy industry (Duffield, 2000; Youssef and El-Ashker, 2017). When it occurs, there are abnormally high levels of circulating ketone bodies, which are detectable in blood, milk, and urine. Serum BHB is the gold standard for defining subclinical ( $>1.4 \mathrm{mmol} / \mathrm{L}$ ) ketosis (Gordon et al., 2013). The etiology of the disease is related to a prolonged negative energy balance in early lactation (Herdt, 2000), along with a marked mobilization of nonesterified fatty acids (NEFA) from the adipose tissue. Under normal conditions, NEFA are completely 
oxidized in the liver to produce energy. When mobilization of NEFA is excessive, oxidation is not completed in the liver, a situation that leads to the production of ketone bodies and their release into the blood (Ingvartsen, 2006). Classically, pathological levels of ketone bodies are reported during the third and fourth weeks following calving (Duffield, 2000). Advances in genetics and feeding management have anticipated metabolic challenges closer to the time of calving, with a higher frequency of pathological peaks of BHB being seen during the first 2 wk following calving (Herdt et al., 1981; Rodriguez-Jimenez et al., 2018).

Ketosis is typically accompanied by a reduction in feed intake (Kaufman et al., 2016) and rumination time (Abuajamieh et al., 2016), and also by a reduction in milk yield (Duffield, 2000). During ketosis, blood levels of NEFA (Chapinal et al., 2011) as well as lactate, positive acute-phase proteins (APP), and proinflammatory cytokines (PIC) increase (Zhang et al., 2016), whereas concentration of negative APP decrease (RodriguezJimenez et al., 2018). Ketosis has also been associated with an impairment of liver function and oxidative stress conditions (Rodriguez-Jimenez et al., 2018). Furthermore, ketosis increases the expression of mRNA for anti-inflammatory genes in the liver (Akbar et al., 2015), and metabolic changes related to the disease negatively affect white blood cell (WBC) functions (Sordillo, 2016). Thus, the onset of ketosis could impair immune function and increase the risk of infectious diseases, such as metritis and mastitis, at the beginning of lactation (Duffield, 2000; Sordillo, 2016).

Prior work detected an association between postpartum ketosis and certain prepartum conditions. A lower DMI and lower frequency of standing behavior prepartum were detected in cows in which subclinical ketosis (SCK) was seen postpartum compared with a control group (Rodriguez-Jimenez et al., 2018). Prepartal increases in blood levels of NEFA (Chapinal et al., 2011) or higher prepartum levels of lactate and IL-6 (Zhang et al., 2016) were associated with a higher risk of developing ketosis postpartum. All of the above conditions are negatively associated with the function of the immune system, including high levels of NEFA (Lacetera et al., 2004); thus, a dysfunctional immune system may cause a higher risk of ketosis postpartum. Our hypothesis is that cows with SCK postpartum are characterized by a dysfunctional immune system during the dry period. We performed a retrospective analysis of blood levels of BHB to detect SCK in postpartum dairy cows with the aim of testing the relationship between SCK onset in early lactation and trends of metabolic and immunological parameters during the dry period, to identify alterations that might reflect a risk for disease occurrence.

\section{MATERIALS AND METHODS}

\section{Experimental Design and Animal Management}

The trial was carried out at the Università Cattolica del Sacro Cuore research dairy barn (Experiment Station, San Bonico, Piacenza, Italy) in accordance with Italian laws on animal experimentation (DL n. 26, 04/03/2014) and ethics (authorization of the Italian Ministry of Health n. 1047/2015-PR). A group of 13 Italian Holstein dairy cows were housed in individual tie-stalls under controlled environmental conditions (room temperature of $20^{\circ} \mathrm{C}$, relative humidity of $65 \%$, $14 \mathrm{~h}$ of light) from -48 to $35 \mathrm{~d}$ from calving (DFC). The expected incidence of SCK was $34 \%$, in accordance with Duffield (2000) and previous experience in our research dairy barn. An ex ante power test of the experimental design $(\alpha=0.05)$ was performed through GPower 3.1 software (Heinrich-Heine-Universität Düsseldorf; www.gpower.hhu.de/) according to Faul et al. (2007). The number of animals to be enrolled in the experiment was calculated to ensure a statistical power $>0.8$ for both plasma NEFA and BHB. All cows were milked twice a day at the stand, at 0400 and $1600 \mathrm{~h}$. Animals were individually fed a component diet offered as 2 equal meals of forage at 12-h intervals and 2 to 8 meals of concentrates supplied by a computer feeder. From -48 until -7 DFC, animals received a hay-based ration with soybean meal and corn silage (phase 1). Seven days before calving, $1 \mathrm{~kg}$ of lactation concentrate was added to the diet (phase 2). After calving, $3 \mathrm{~kg}$ of alfalfa-dehydrated hay and $2 \mathrm{~kg} / \mathrm{wk}$ of corn silage (to a maximum of $20 \mathrm{~kg} / \mathrm{d}$ ) were added to the diet. Grass hay was gradually reduced to 2 to $2.5 \mathrm{~kg} / \mathrm{d}$ and the concentrate was increased by $0.5 \mathrm{~kg} / \mathrm{d}$ to satisfy the requirement of $1 \mathrm{~kg} / 3 \mathrm{~kg}$ of produced milk (phases 3 and 4). The same batches of hay and corn silage were used during the trial. Feeds were collected every 2 wk, and, after DM determination, samples were pooled for subsequent analyses. The feeds and diet composition are shown in Table 1. Periodic checks were performed, and blood samples were collected regularly during the trial, according to the time schedule shown in Figure 1 and described in the following sections.

\section{BW, BCS, DMI, Rumination Time, and Milk Yield}

Every 2 wk, BW was measured in the morning before feeding, and BCS was determined by the same operator using a 1 to 4 scale system (Agricultural Development and Advisory Service, 1986). The BCS variation $(\triangle \mathrm{BCS})$ was calculated as the difference between data at calving day and at $35 \mathrm{DFC}$. The daily individual feed intake was measured by weighing the amounts 
of feed administered and their refusals. The DMI was calculated using the DM content of each feed. Rumination time was registered daily using the Ruminact system (SCR Europe, Podenzano, Italy), and data were processed according to Soriani et al. (2012). Milk yield was weighed after each milking. Daily values of DMI, rumination time, and milk yield were expressed as average weekly values.

\section{Health Status}

Health condition of the cows was monitored daily, and all of the veterinary interventions that occurred from -48 to 35 DFC were recorded. Body tempera- ture was measured daily with a rumen bolus (DVM Systems TempTrack, HerdStrong LLC, Greeley, CO). Conditions affecting the cow health were diagnosed as follows: mastitis by visual evaluation of abnormal milk from each quarter and an SCC analysis in suspicious cases; a retained placenta when the fetal membranes were not expelled within $24 \mathrm{~h}$ after calving; clinical endometritis and metritis according to Sheldon et al. (2006); and milk fever, displacement of the abomasum, and pneumonia by inspection of a veterinary practitioner. Diarrhea was diagnosed by visual evaluation of the consistency and color of feces according to the fecal score method (Ireland-Perry and Stallings, 1993), assuming that diarrheic feces had a fecal score of 2 or less.

Table 1. Composition (\% of DM unless otherwise noted) and characteristics of the experimental diets fed during the 5 experimental phases

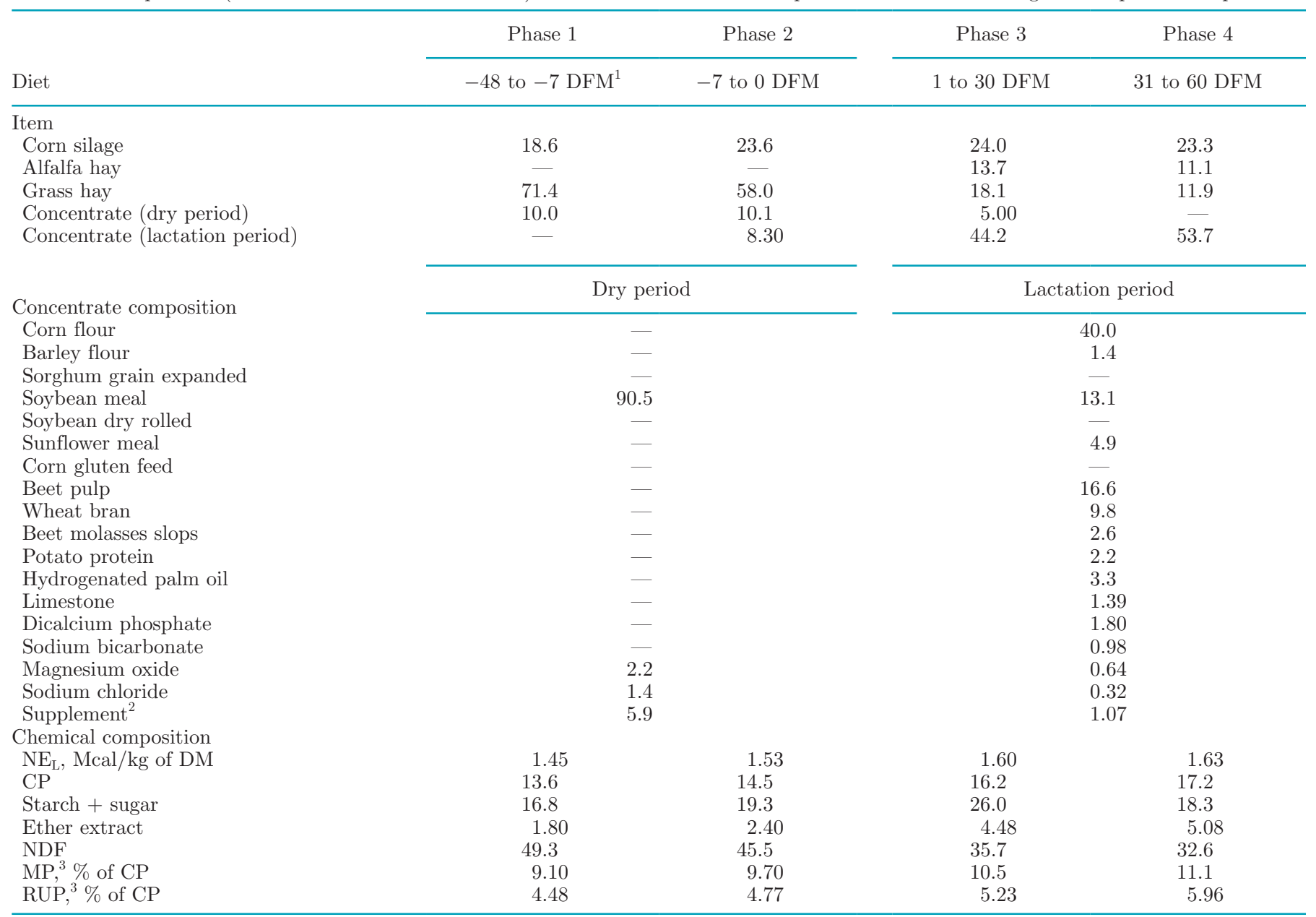

${ }^{1} \mathrm{DFM}=$ days from calving. Between -55 and $-48 \mathrm{~d}$ from calving, cows received grass hay only.

${ }^{2}$ Supplements were composited to provide 150,000 IU of vitamin A, 10,000 IU of vitamin D, $200 \mathrm{mg}$ of vitamin E, $100 \mathrm{mg}$ of vitamin K, $100 \mathrm{mg}$ of 4-aminobenzoic acid, $50 \mathrm{mg}$ of vitamin $\mathrm{B}_{1}, 0.5 \mathrm{mg}$ of vitamin $\mathrm{B}_{12}, 500 \mathrm{mg}$ of niacin, $4000 \mathrm{mg}$ of choline, $350 \mathrm{mg}$ of Mn, $800 \mathrm{mg}$ of $\mathrm{Zn}$, $40 \mathrm{mg}$ of $\mathrm{Cu}, 20 \mathrm{mg}$ of $\mathrm{I}, 1 \mathrm{mg}$ of $\mathrm{Co}, 1 \mathrm{mg}$ of Se.

${ }^{3}$ Estimated using NRC (2001). 


\section{Blood Sample Collection}

Blood samples were collected by means of jugular venipuncture into evacuated tubes (BD Vacutainer, Becton, Dickinson and Co., Franklin Lakes, NJ) before the morning feeding. Samples were used to perform different assays (Figure 1).

Metabolic Profile Assessment. For the metabolic profile assessment, samples were collected into heparinized tubes at $-48,-28,-21,-14,-7,-3,0,1,3,7,14$, and $28 \pm 2$ DFC (Figure 1) and processed as described by Calamari et al. (2016). A clinical autoanalyzer (ILAB-650, Instrumentation Laboratory, Bedford, MA) was used to determine the concentration of glucose, NEFA, BHB, urea, creatinine, calcium, phosphorus, magnesium, sodium, potassium, chlorine, zinc, aspartate amino transferase-glutamate oxaloacetate transaminase (AST-GOT), $\gamma$-glutamyl transferase (GGT), alkaline phosphatase, total protein, haptoglobin, ceruloplasmin, albumin, total bilirubin, cholesterol, and globulin in accordance with Calamari et al. (2016). The reactive oxygen metabolites (ROMt), ferric-reducing antioxidant power, nitrates $\left(\mathrm{NO}_{3}\right)$, nitrites $\left(\mathrm{NO}_{2}\right)$, and nitric oxides (NOx) were determined according to Jacometo et al. (2015); paraoxonase according to Bionaz et al. (2007); thiol groups according to Minuti et al. (2014); myeloperoxidase according to Bradley et al. (1982); and advanced oxidation protein products (AOPP) according to Hanasand et al. (2012). Finally, L-lactic acid and D-lactic acid were determined by using a commercial kit (K-DLATE, Megazyme, Bray, Co. Wicklow, Ireland). A multidetection microplate reader (Synergy 2, BioTek Instruments, Winooski, VT) and commercial kits for the ELISA method were used to

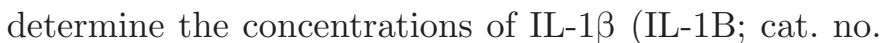
ESS0027; Thermo Fisher Scientific, Frederick, MD) and IL-6 (cat. no. ESS0029; Thermo Fisher Scientific) according to Jahan et al. (2015) and Trevisi et al. (2015) of serum amyloid $\alpha$ (Phase SAA Assay, cat. no. TP-802, Tridelta Development Ltd., Maynooth, Co. Kildare, Ireland). Commercial kits for cytokines were validated for cell culture media; therefore, we validated their use in plasma before running the analysis. Linearity with plasma matrix was found up to a $1: 2$
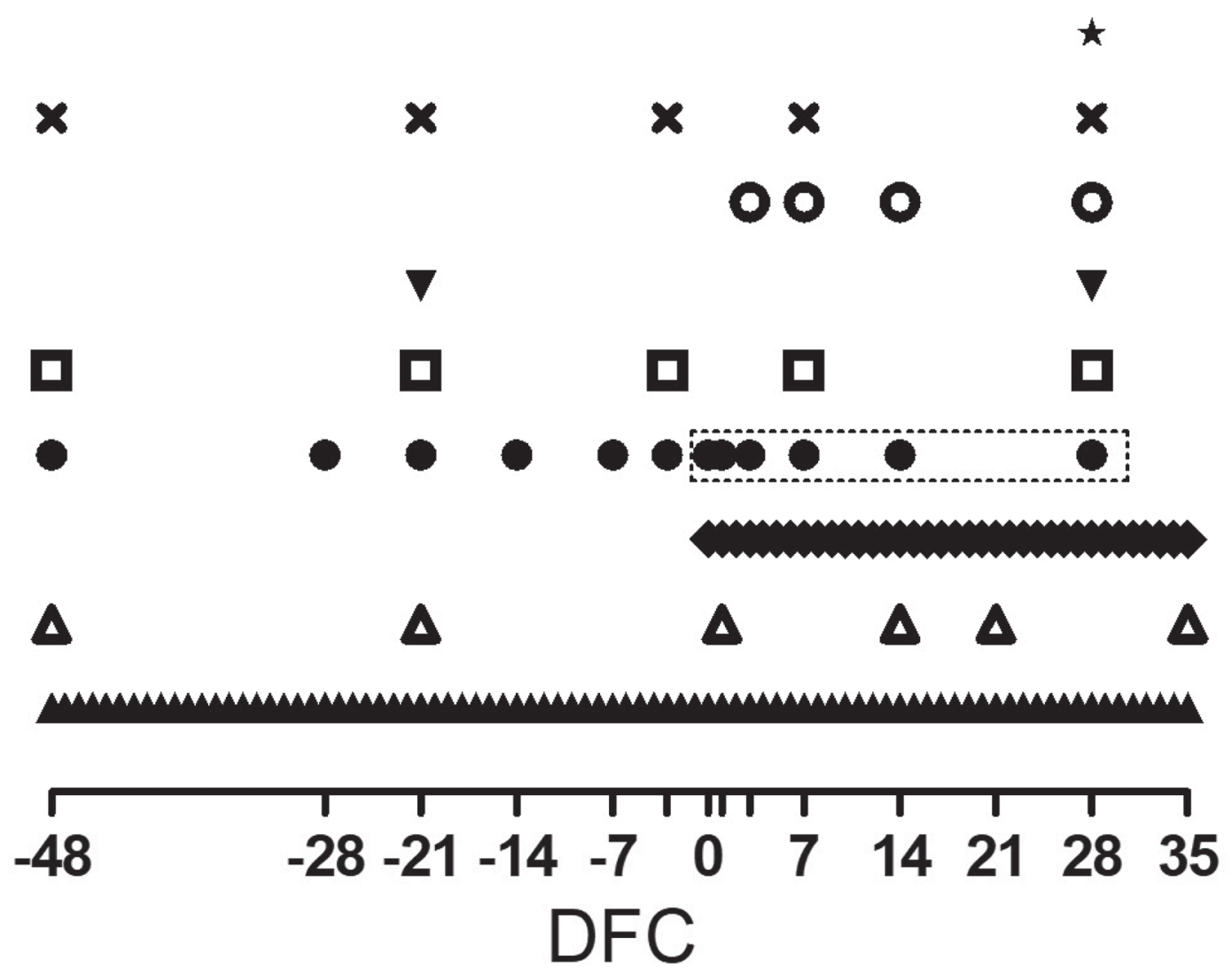

Figure 1. Scheduled time points, expressed as day from calving (DFC), for rumen sample collection (star), carrageenan skin test performance $(\times)$, milk sample collection $(\bigcirc)$, blood sample collection for the interferon gamma release assay $(\mathbf{\nabla})$, blood sample collection for white blood cells profile and whole blood stimulation assay $(\square)$, blood sample collection for metabolic profile $(\bullet$; time points surrounded with dotted lines were used in the retrospective analysis of BHB), milk yield measurement $(\bullet)$, BW and BCS determination $(\Delta)$, DMI and rumination time determination $(\mathbf{\Lambda})$. 
dilution for IL-6 (recovery upon addition was 115.9\%) and from 1:2 to 1:32 dilution for IL-1B. The oxygen reactive antioxidant capacity (ORAC) was determined by using a fluorometric method according to Jacometo et al. (2015). Concentrations of retinol, tocopherol, and $\beta$-carotene were analyzed by reversed-phase HPLC (LC-4000, Jasco Europe SRL, Cremella, Italy), as described by Jahan et al. (2015). Further details on the analytical procedures adopted in blood analysis are reported in Supplemental File S1 (https://doi.org/10 .3168/jds.2019-16497).

$W B C$ Profile. For the WBC profile (Figure 1), samples were collected in K-EDTA tubes at $-48,-21$, 3,7 , and $28 \pm 2 \mathrm{DFC}$ and processed using a clinical autoanalyzer (Cell-DYN 3700, Abbott Diagnostics, Santa Clara, CA). A laser optics assay was used to determine total counts of WBC, neutrophils, monocytes, and basophils. The mean cell volume and number of platelets were determined via an electrical impedance assay. The hemoglobin and mean cell hemoglobin counts were determined using a spectrophotometry assay.

Whole-Blood Stimulation Assay. For the wholeblood stimulation assay (WBA), blood samples were collected in heparinized serum tubes at $-48,-21,3$, 7 , and $28 \pm 2$ DFC (Figure 1) and stimulated with 0 (baseline), 0.01 (low dose), or $5 \mu \mathrm{g} / \mathrm{mL}$ (high dose) of bacterial LPS (Escherichia coli O111:B4; SigmaAldrich, St. Louis, MO; cat. no. L3012), according to Jahan et al. (2015). After the WBA, plasma samples were stored at $-80^{\circ} \mathrm{C}$ for the measurement of glucose, D-lactic acid, L-lactic acid, IL-1B, IL-6, $\mathrm{NOx}, \mathrm{NO}_{2}$, and $\mathrm{NO}_{3}$. Variations of the plasma parameters after the WBA with low and high doses of LPS were expressed as fold changes relative to the baseline.

IFN- $\gamma$ Release Assay. For the IFN- $\gamma$ (IFNG) release assay, whole-blood samples were collected into heparinized tubes at -28 and 28 DFC (Figure 1). After collection, the tubes were stored vertically in a warm bath at $38.4^{\circ} \mathrm{C}$ according to Røntved et al. (2005) and transported to the laboratory within $20 \mathrm{~min}$ for the stimulation procedure. Whole blood was used in an IFNG release assay for Mycobacterium avium according to Lauzi et al. (2000; internal method IZSLER, MP 13/011). Briefly, two 1-mL aliquots of each blood sample were distributed in a 24-well tissue culture microtiter plate. One well was supplemented with 100 $\mu \mathrm{L}$ of a 1:10 dilution $(0.5 \mathrm{mg} / \mathrm{mL})$ of Mycobacterium avium purified protein derivative (PPD, IZS Umbria e Marche, Perugia, Italy) in PBS, and the other well was supplemented with $100 \mu \mathrm{L}$ of a sterile PBS as a control. The plate was positioned in a heated incubator (HIR $10 \mathrm{M}$, Boekel Scientific, Feasterville, PA) set to $38.4^{\circ} \mathrm{C}$ and with a relative humidity of $95 \%$ for $24 \mathrm{~h}$. After incubation, the blood was centrifuged at $8,500 \times g$ for
16 min at $4^{\circ} \mathrm{C}$ and the plasma was stored at $-20^{\circ} \mathrm{C}$ until use. The plasma was later thawed and analyzed with a commercial ELISA kit for bovine IFNG (Bovigam 2G TB Kit, cat. no. 63330, Thermo Fisher Scientific Prionics AG, Schlieren-Zurich, Switzerland) according to the manufacturer's directions. Results were evaluated in terms of the optical density difference between the avian PPD-stimulated and control wells.

\section{Milk Sample Collection and Analysis}

Milk samples were collected during the morning milking at 1, 3, 14, and 28 DFC (Figure 1) into 100$\mathrm{mL}$ polypropylene bottles. Butterfat, protein, lactose and casein contents, titratable acidity, and coagulation properties (rennet clotting time and curd firmness at $30 \mathrm{~min}$ ) were measured by infrared instrumentation (MilkoScan FT 120, Foss Analytics, Hillerød, Denmark) according to Calamari et al. (2010) and Chessa et al. (2014). The outputs of fat and protein and the fat-to-protein ratio were also calculated. Urea nitrogen was determined in skim milk by a spectrophotometric assay, using a urea nitrogen kit (cat. no. 0018255440, Instrumentation Laboratory, SpA, Milano, Italy) and a clinical autoanalyzer (ILAB-650, Instrumentation Laboratory, Bedford, MA). The SCC was determined using an optical fluorimetric method with an automated cell counter (Fossomatic-180, Foss Analytics).

\section{Carrageenan Skin Test}

The carrageenan skin test (CST) was performed as specified by Jahan et al. (2015) to evaluate the peripheral immune responses at $-48,-21,3,7$, and $28 \pm 2$ DFC (Figure 1). Skin thickness was measured using a skinfold caliper (cat. no. 470119-588, VWR, Radnor, PA) immediately before carrageenan injection $(0 \mathrm{~d})$ and then at 2 and $9 \mathrm{~d}$ after injection. The total response of each challenge was calculated as the area under the curve of the thickness, measured at $\mathrm{d} 2$ and 9 , subtracting the thickness measured at $\mathrm{d} 0$.

\section{Rumen Fluid Parameters}

Rumen fluid samples were collected with an orogastric probe (Ruminator, Proofs Products, Guelph, ON, Canada) before the morning feed administration. The $\mathrm{pH}$ was immediately measured with a $\mathrm{pH}$ meter (GLP 21, Crison Instruments SA, Alella, Barcelona, Spain). A 2-mL aliquot of the supernatant was transferred into tubes with $1 \mathrm{~mL}$ of $0.12 M$ oxalic acid and immediately frozen at $-20^{\circ} \mathrm{C}$ for later analysis. The concentration of total VFA and molar proportions of acetic, propionic, butyric, isobutyric, valeric, isovaleric, caproic, 
isocaproic, and enanthic acids were analyzed as previously described (Minuti et al., 2014). Concentrations of single VFA were expressed as amounts relative to the total VFA concentration. A spectrophotometric clinical autoanalyzer (ILAB-650, Instrumentation Laboratory, Bedford, MA) and commercial kits for urea nitrogen (cat. no. 0018255440, Instrumentation Laboratory, Milano, Italy) and lactate (K-DLATE, Megazyme) were used to assess concentrations of ammonia, L-lactic acid, D-lactic acid, and total lactic acid, respectively.

\section{Retrospective Analyses and Animal Grouping}

Animals were retrospectively divided into 2 groups based on their BHB levels measured in 6 blood samples collected between 0 and 28 DFC (Figure 1), assuming a threshold of $1.4 \mathrm{mmol} / \mathrm{L}$ as a cut-off point (Duffield, 2000). When the blood levels of BHB reached the subclinical threshold at least in 1 out of 6 samples collected, animals were considered affected by subclinical ketosis (KET; 6 cows), and when levels remained below this threshold, animals were used as control cows (CTR; 7 cows). In the KET group, occurred at $6.1 \pm$ $4.7 \mathrm{~d}$ postpartum.

\section{Statistical Analysis}

Data in the tables are presented as the mean \pm standard error. Before analysis, the normality of distributions was verified for each parameter by reckoning the skewness and kurtosis according to the Shapiro test of SAS (SAS Institute Inc., Cary NC). Non-normally distributed parameters were normalized through natural logarithms (among plasma parameters, IL-1B, IL-6, glucose, NEFA, D-lactic acid, L-lactic acid, magnesium, AST-GOT, GGT, haptoglobin, bilirubin, cholesterol, AOPP, tocopherol, $\beta$-carotene, $\mathrm{NOx}, \mathrm{NO}_{2}$, and $\mathrm{NO}_{3}$; among the WBC profile, total WBC, neutrophils, neutrophil-to-lymphocyte ratio, monocytes, eosinophils, and basophils; among milk parameters, butterfat, fat output, and fat-to-protein ratio; among rumen fluid parameters, ammonia; among the WBA parameters, fold changes of D-lactic acid, IL-1B, IL-6, NOx, and $\mathrm{NO}_{3}$, and the total response to CST) or the square root transformation (among the plasma parameters, calcium) and back transformed for plotting in tables and graphs.

Data on BW, BCS, DMI, rumination time, milk yield, metabolic and WBC profiles, WBA, milk quality parameters, response to IFNG release assay, and CST were submitted for ANOVA testing using a mixed model for repeated measures (Mixed Procedure, SAS Institute Inc.) in accordance with Littell et al. (1998). The statistical model included the fixed effect of the health status (Hs) for CTR and KET cows, time (t), and their interaction $(\mathrm{Hs} \times \mathrm{t})$. For those parameters that were measured daily (DMI, rumination time, and milk yield), the time effect considered the average weekly value, whereas for other parameters (BW, BCS, metabolic and WBC profiles, WBA, milk quality parameters, IFNG release assay, and CST), the time effect considered a single DFC. The time was considered as a repeated measure for each cow. For the WBA, the dose (D; low and high) and the full interaction effect (Hs $\times$ $\mathrm{t} \times \mathrm{D})$ were also considered. The analysis was carried out using 3 covariance structures: autoregressive order, compound symmetry, and spatial power. These were ranked according to their Akaike information criterion, with the one having the lowest criterion being eventually chosen (Littell et al., 1998). The pairwise comparison was done using the least significant difference test. Data on rumen fluid parameters were analyzed by a one-way ANOVA (GLM procedure, SAS Institute Inc.), considering only the fixed effect of Hs.

Post hoc comparisons were discussed when the $P$ value for the main effect was $\leq 0.05$. Main effects at $P$ $\leq 0.10$ are discussed in the context of tendencies.

\section{RESULTS}

\section{BW, BCS, DMI, Rumination Time, and Milk Yield}

The BW, BCS, and $\triangle \mathrm{BCS}$ were numerically higher in KET cows than in CTR cows during the entire experimental period, but no effect was detected (Supplemental File S2; https://doi.org/10.3168/jds.2019-16497). The DMI, rumination time, and milk yield (Figure 2a-c) were lower in KET cows than in CTR cows after calving ( $\mathrm{Hs} \times \mathrm{t} ; P<0.01)$.

\section{Milk Quality Parameters}

Among milk quality and rheological parameters (Supplemental File S3; https://doi.org/10.3168/jds .2019-16497), both fat and protein outputs were lower in the KET group than in the CTR group at 28 DFC $(\mathrm{Hs} \times \mathrm{t}=0.02$ and 0.05 , respectively). Urea $\mathrm{N}$ had a tendency toward an $\mathrm{Hs} \times \mathrm{t}$ effect; its levels were lower in the KET group than the CTR group at $7 \mathrm{DFC}$ and numerically lower thereafter. No effect was detected on other parameters.

\section{Rumen Fluid Parameters}

Among the rumen fluid parameters (Supplemental File S4; https://doi.org/10.3168/jds.2019-16497), KET cows had a tendency toward a higher molar proportion of butyric acid and a lower molar proportion of 


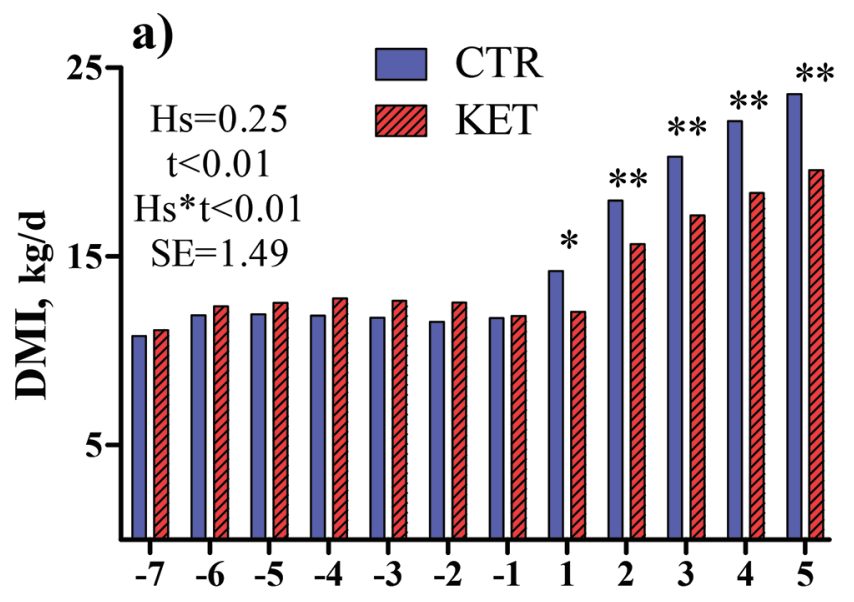

b)
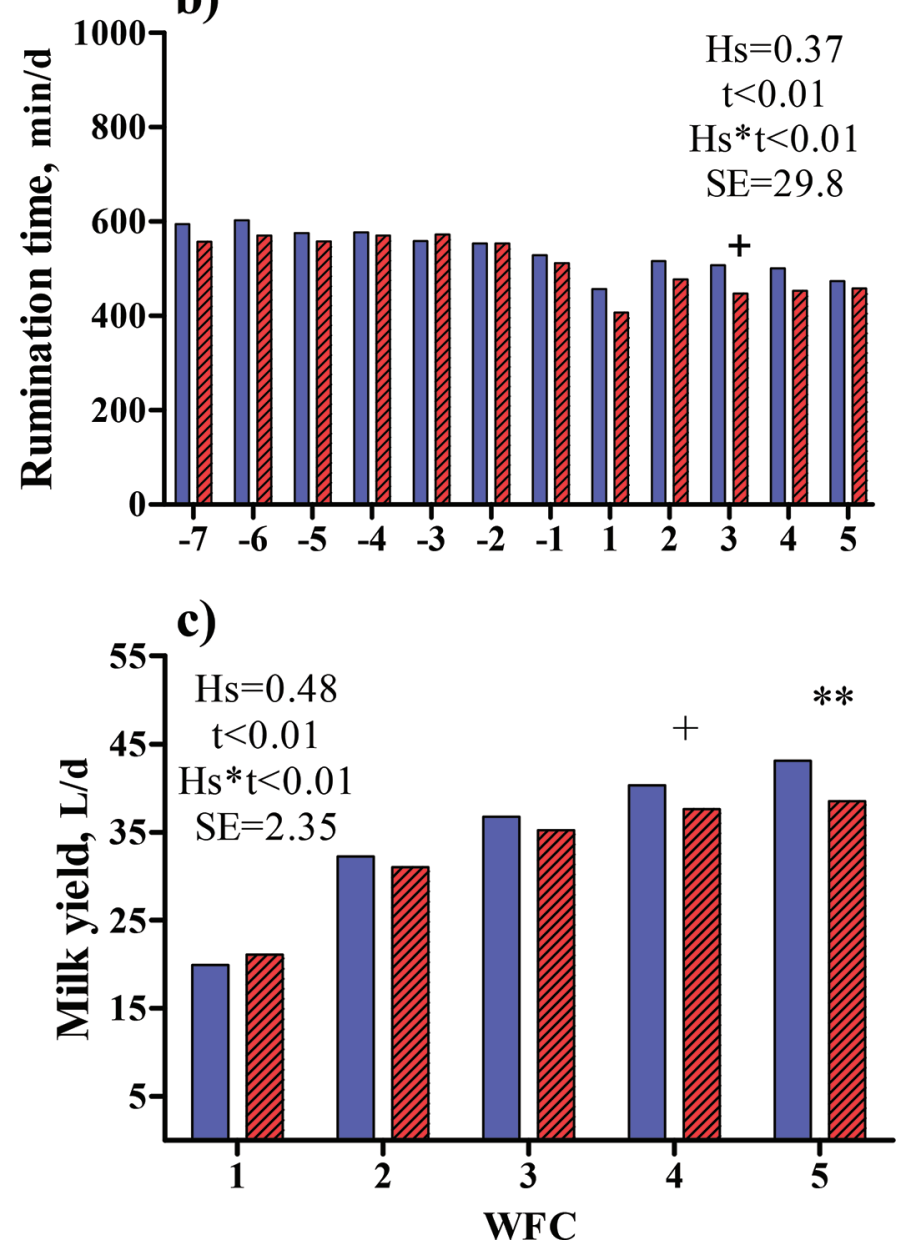

Figure 2. Average week values of DMI (a), rumination time (b), and milk yield (c) in control dairy cows (CTR) and cows with BHB $>1.4 \mathrm{mmol} / \mathrm{L}$ in the first month of lactation (KET). ${ }^{* *} P<0.01 ;{ }^{*} P<$ $0.05 ;+P<0.1$; WFC is weeks from calving; $\mathrm{Hs}=$ health status effect; $\mathrm{t}=$ time effect; Hs $\times \mathrm{t}=$ health status $\times$ time interaction effect; SE is the average standard error of the model. valeric acids ( $\mathrm{Hs}=0.08$ and 0.07 , respectively) and a lower molar proportion of isovaleric acid $(\mathrm{Hs}=0.05)$ compared with the CTR group. No effect appeared for other parameters.

\section{Metabolic Profile}

Hematocrit and Biomarkers of Energy, Protein, and Mineral Metabolism. The packed cell volume (Supplemental File S5a; https://doi.org/10 .3168/jds.2019-16497) was not affected by Hs. Among the energy metabolism biomarkers, glucose concentration (Figure 3a) was higher in the KET group than the CTR group at -48 and -7 DFC, but the KET group had a more marked decrease at 3 DFC and lower concentrations than the CTR group thereafter $(\mathrm{Hs} \times \mathrm{t}$ $<0.01$ ). The concentrations of NEFA and BHB (Figure $3 \mathrm{~b}, \mathrm{c})$ were higher in the KET group than the CTR group during the entire experimental period ( $\mathrm{Hs}=$ 0.01 and $<0.01$, respectively), with larger differences observed after parturition ( $\mathrm{Hs} \times \mathrm{t}=0.02$ for $\mathrm{BHB}$ ). The concentrations of L-lactic acid and D-lactic acid (Figure 3d, e) were lower in the KET group than the CTR group before calving, but both had a more pronounced peak at calving in the KET group, resulting in a higher level than in the CTR group thereafter (Hs $\times \mathrm{t}=0.01)$. Among the protein metabolism biomarkers (Figure 3f, g), the urea concentration was lower in the KET group than in the CTR group at $14 \mathrm{DFC}$ $(\mathrm{Hs} \times \mathrm{t}<0.01)$, whereas the creatinine concentration was higher overall during the examined period $(\mathrm{Hs}=$ 0.04). Among the mineral metabolism biomarkers, concentrations of phosphorus, sodium, potassium, and zinc (Figure 3h-1) were lower in the KET group than in the CTR group during the entire experimental period (Hs $<0.01$ for phosphorus and potassium; $\mathrm{Hs}=0.03$ for sodium and zinc). Concentrations of chlorine (Figure $3 \mathrm{k}$ ) were higher in the KET group than in the CTR group before calving $(\mathrm{Hs}=0.02)$. Concentrations of calcium and magnesium did not differ between the 2 groups (Supplemental File S5b,c; https://doi.org/10 .3168/jds.2019-16497).

Liver Function Biomarkers. Concentrations of AST-GOT and total bilirubin (Figure 4a and c) were higher in the KET group than in the CTR group after calving ( $\mathrm{Hs} \times \mathrm{t}<0.01$ and $=0.05$, respectively). The concentration of GGT (Figure $4 \mathrm{~b}$ ) tended to be higher in the KET group than the CTR group both before and after calving $(\mathrm{Hs}=0.06 ; \mathrm{Hs} \times \mathrm{t}=0.09)$. Alkaline phosphatase concentrations (Figure 4d) had a tendency toward an $\mathrm{Hs} \times \mathrm{t}$ effect, so that they were numerically higher in the KET cows than in CTR cows after calving. 
Inflammation Biomarkers. Concentrations of perimental period (Hs $<0.01)$. No effects were detected myeloperoxidase (Figure 4e) were higher in the KET for total protein or globulin (Supplemental File S5d, group than in the CTR group during the entire ex- e; https://doi.org/10.3168/jds.2019-16497). Among the
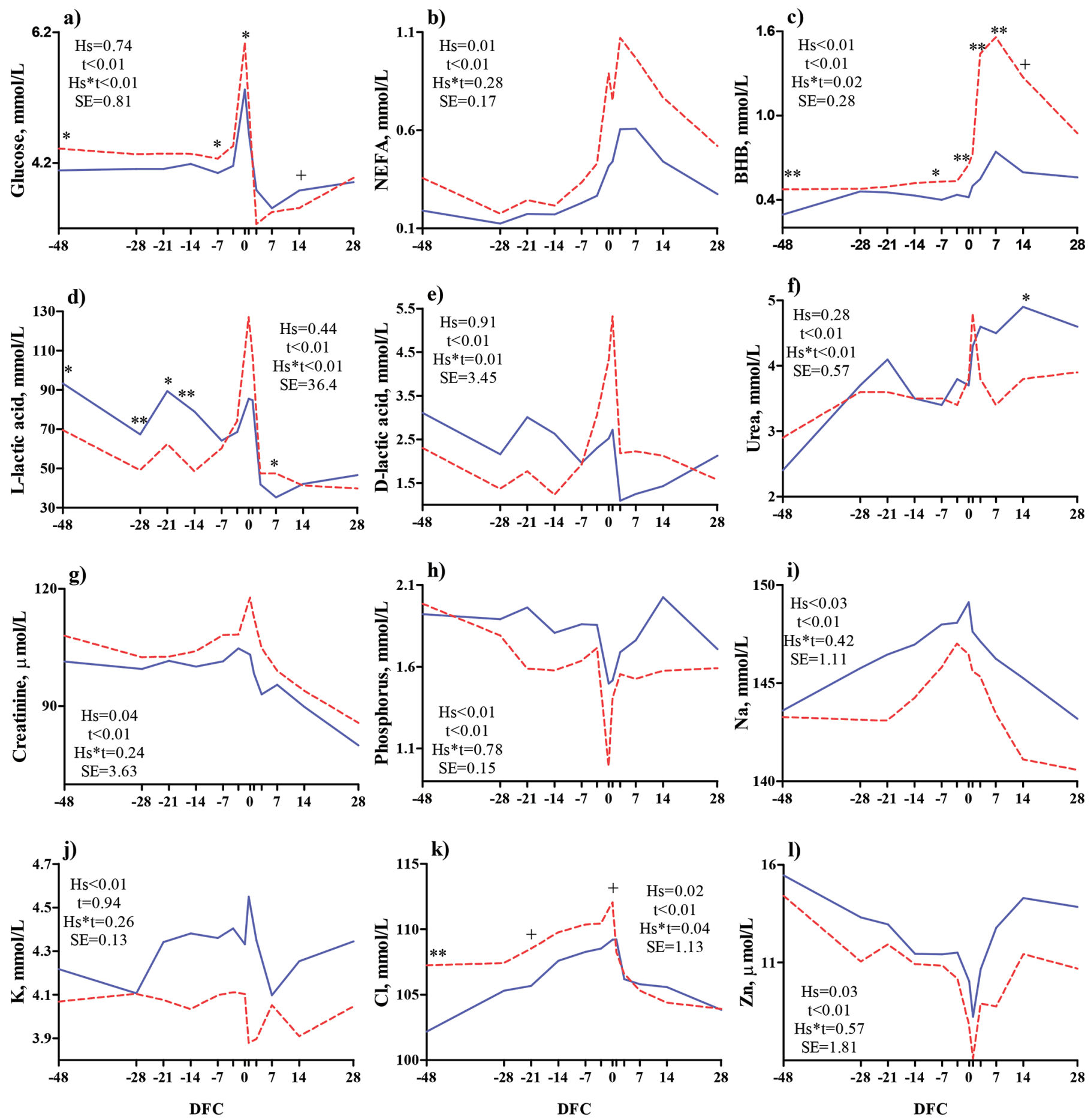

Figure 3. Time course of plasma concentrations of glucose (a), nonesterified fatty acids (NEFA; b), BHB (c), L-lactic acid (d), D-lactic acid (e), urea (f), creatinine (g), phosphorus (h), sodium (i), potassium (j), chlorine (k), and zinc (l) in control dairy cows (CTR; solid blue line) and cows with BHB $>1.4 \mathrm{mmol} / \mathrm{L}$ in the first month of lactation (KET; dashed red line). ${ }^{*} P<0.01$; ${ }^{*} P<0.05$; $+P<0.1$; DFC is days from calving; $\mathrm{Hs}=$ health status effect; $\mathrm{t}=$ time effect; $\mathrm{Hs} \times \mathrm{t}=$ health status $\times$ time interaction effect; SE is the average standard error of the model. 
positive APP, haptoglobin levels (Figure 4f) were higher in the KET group than the CTR group beginning in the second week after calving (Hs $\times \mathrm{t}=0.01)$. Concentrations of ceruloplasmin and serum amyloid $\alpha$ (Figure $4 \mathrm{~g}, \mathrm{~h}$ ) were higher in the KET group than in the CTR group after calving $(\mathrm{Hs}=0.09$ and 0.05 , respectively; $\mathrm{Hs} \times \mathrm{t}=0.01$ and 0.03 , respectively). Among the negative APP, retinol levels (Figure 4i) were lower in the KET group than the CTR group after calving ( $\mathrm{Hs} \times \mathrm{t}$ $<0.01$ ), whereas paraoxonase levels were higher in the KET cows compared with the CTR cows before calving $(\mathrm{Hs}=0.06)$, with differences disappearing after parturition (Figure 5a). No difference between groups was detected for albumin and cholesterol (Supplemental File S5f, g; https://doi.org/10.3168/jds.2019-16497). Concentrations of IL-1B and IL-6 (Figure 5b, c) were higher in the KET group than the CTR group before calving ( $\mathrm{Hs} \times \mathrm{t}=0.03$ and 0.05 , respectively).

Oxidative Stress Biomarkers. Concentrations of ROMt, thiol groups, and AOPP (Figure $5 \mathrm{~d}-\mathrm{f}$ ) were higher in the KET group than in the CTR group (Hs $<0.01$ ), and a tendency for an $\mathrm{Hs} \times \mathrm{t}$ effect was observed for ROMt. Concentrations of $\mathrm{NOx}$ and $\mathrm{NO}_{3}$ (Figure 5g, h) were higher in the KET group than the CTR group (Hs $=0.02$ and 0.01 , respectively). Concentrations of ferric-reducing antioxidant power, oxygen reactive anti-
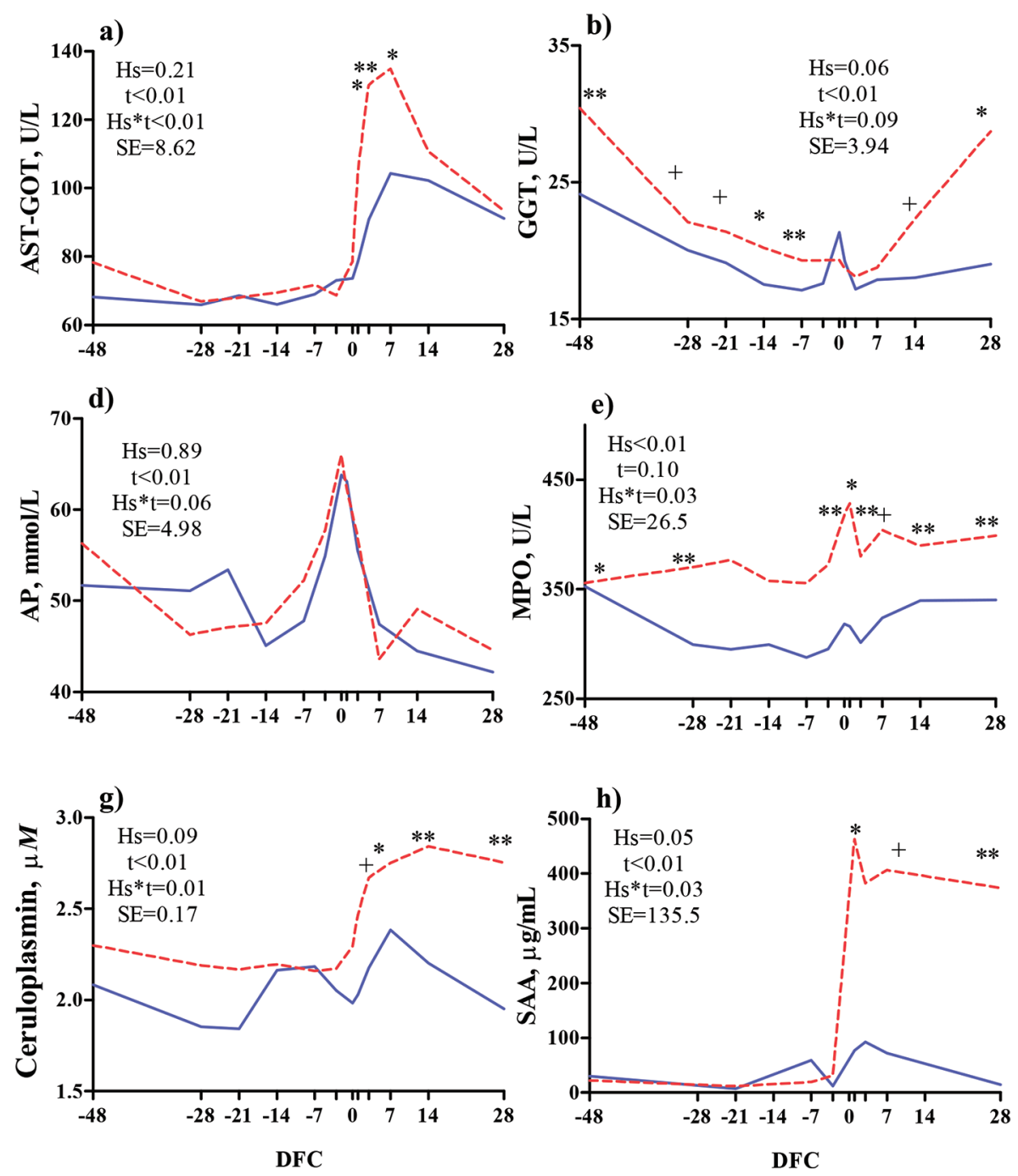
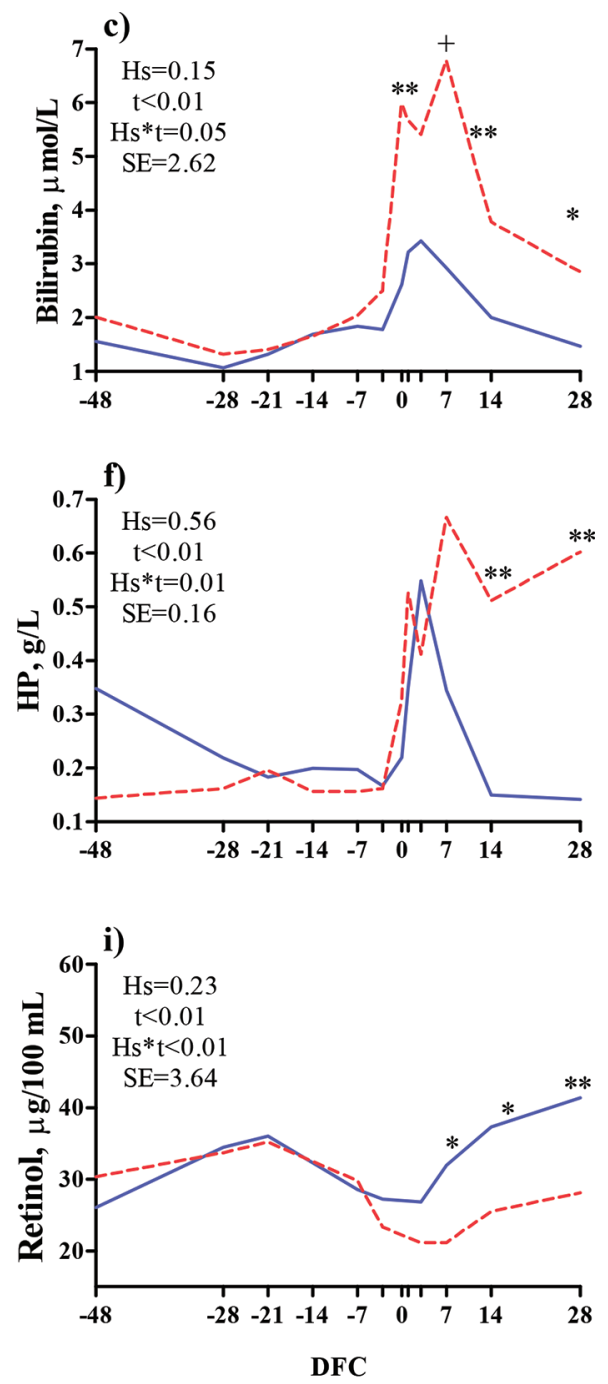

Figure 4. Time course of plasma concentrations of aspartate amino transferase (AST-GOT; a), gamma glutamyl transferase (GGT; b), bilirubin (c), alkaline phosphatase (AP; d), myeloperoxidase (MPO; e), haptoglobin (HP; f), ceruloplasmin (g), serum amyloid $\alpha$ (SAA; h), and retinol (i) in control dairy cows (CTR; solid blue line) and cows with BHB $>1.4 \mathrm{mmol} / \mathrm{L}$ in the first month of lactation (KET; dashed red line). ${ }^{*} P<0.01 ;{ }^{*} P<0.05 ;+P<0.1 ;$ DFC is days from calving; Hs $=$ health status effect; $\mathrm{t}=$ time effect; Hs $\times \mathrm{t}=$ health status $\times$ time interaction effect; $\mathrm{SE}$ is the average standard error of the model. 
oxidant capacity, tocopherol, $\beta$-carotene, and $\mathrm{NO}_{2}$ were not different between groups (Supplemental File S5h-l; https://doi.org/10.3168/jds.2019-16497).

\section{WBC Profile}

Results of the WBC profile are reported in Supplemental File S6 (https://doi.org/10.3168/jds.2019 -16497). The total WBC and neutrophil counts were greater in the KET group than in the CTR group at $28 \mathrm{DFC}(\mathrm{Hs} \times \mathrm{t}=0.03$ and 0.02 , respectively). The prevalence of monocytes and basophils was higher in the KET group than in the CTR group during the entire experimental period ( $\mathrm{Hs}=0.04$ and 0.02 , respec- tively). The concentration of hemoglobin was higher in the KET group than in the CTR group at -48 DFC $(\mathrm{Hs} \times \mathrm{t}=0.01)$. The mean cell volume and mean cell hemoglobin were greater in the KET group than in the CTR group (Hs <0.01 for both). The prevalence of platelets was greater in the KET group than in the CTR group at -21 and -3 DFC $(\mathrm{Hs} \times \mathrm{t}<0.01)$.

$W B A$. The amount of cytokines produced in vitro by WBC increased after the WBA (Table 2). The production of IL-1B was lower overall in the KET group than in the CTR group between -21 and 7 DFC (Hs and $\mathrm{Hs} \times \mathrm{t}<0.01$ ). The production of IL- 6 by WBC was higher in the KET group than the CTR group at 7 and $28 \mathrm{DFC}(\mathrm{Hs}=0.04 ; \mathrm{Hs} \times \mathrm{t}=0.01)$.
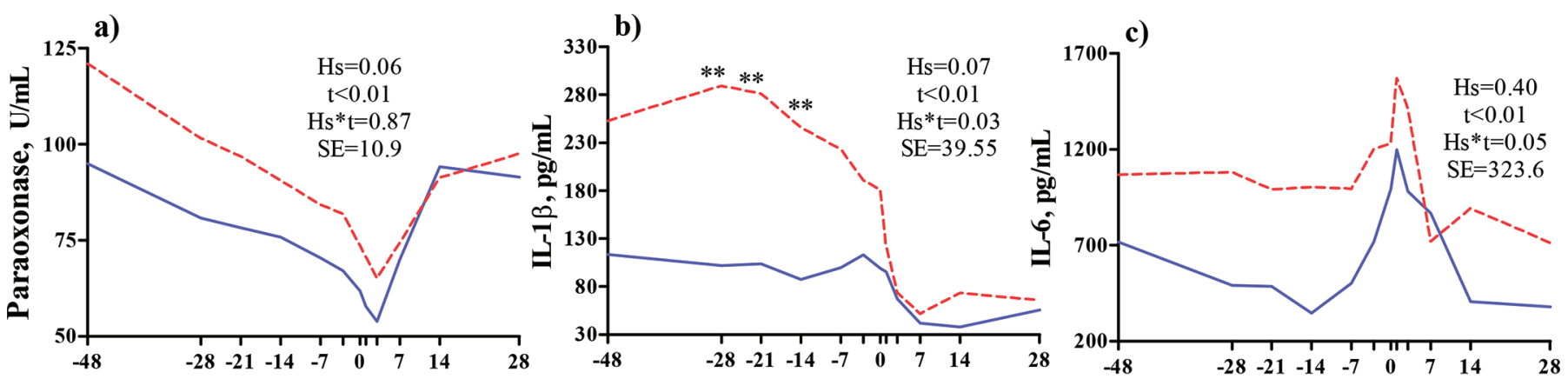
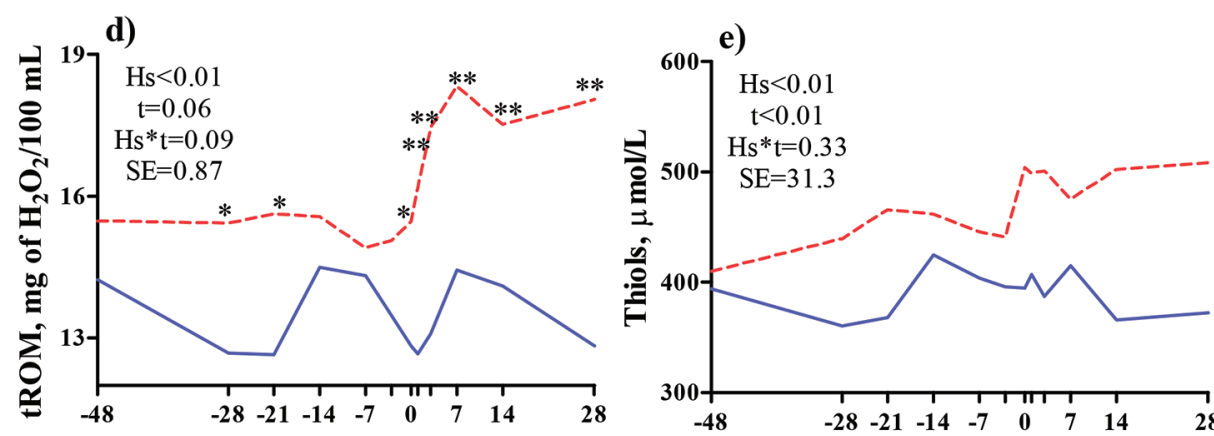

h)
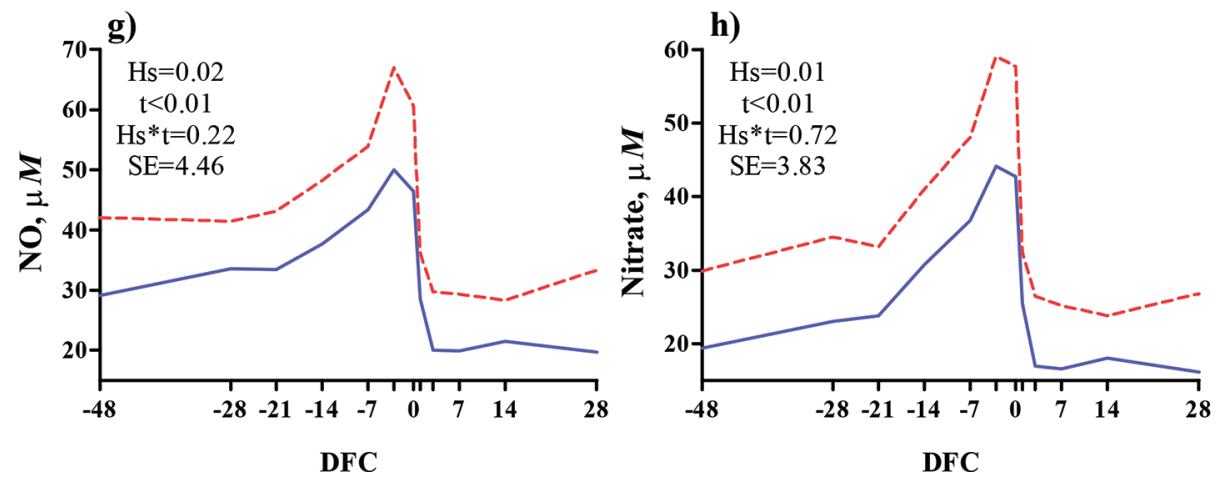

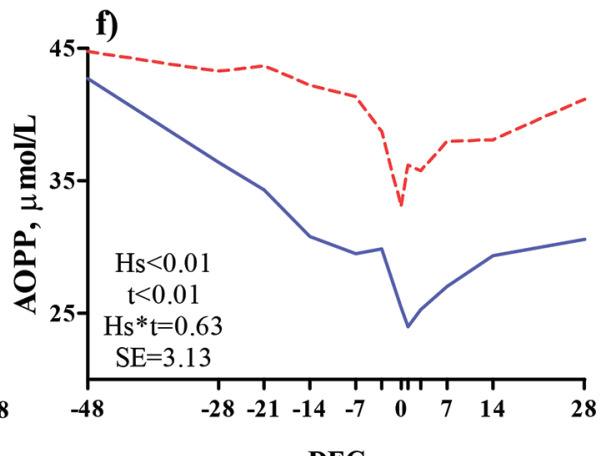

DFC

Figure 5. Time course of plasma concentrations of paraoxonase (a), IL-1 (b), IL-6 (c), total reactive oxygen metabolites (tROM; d), thiol groups (e), advanced oxidation protein products (AOPP; $\mathrm{f}$ ), nitric oxide (NO; g), and nitrate (h) in control dairy cows (CTR; solid blue line) and cows with $\mathrm{BHB}>1.4 \mathrm{mmol} / \mathrm{L}$ in the first month of lactation (KET; dashed red line). ${ }^{* *} P<0.01 ;{ }^{*} P<0.05 ;+P<0.1 ; \mathrm{DFC}$ is days from calving; $\mathrm{Hs}=$ health status effect; $\mathrm{t}=$ time effect; $\mathrm{Hs} \times \mathrm{t}=$ health status $\times$ time interaction effect; SE is the average standard error of the model. 
Table 2. Fold changes of cytokines in a whole-blood stimulation assay with a low or high dose of bacterial LPS in control dairy cows or cows with BHB levels $>1.4 \mathrm{mmol} / \mathrm{L}$ in the first month of lactation ${ }^{1}$

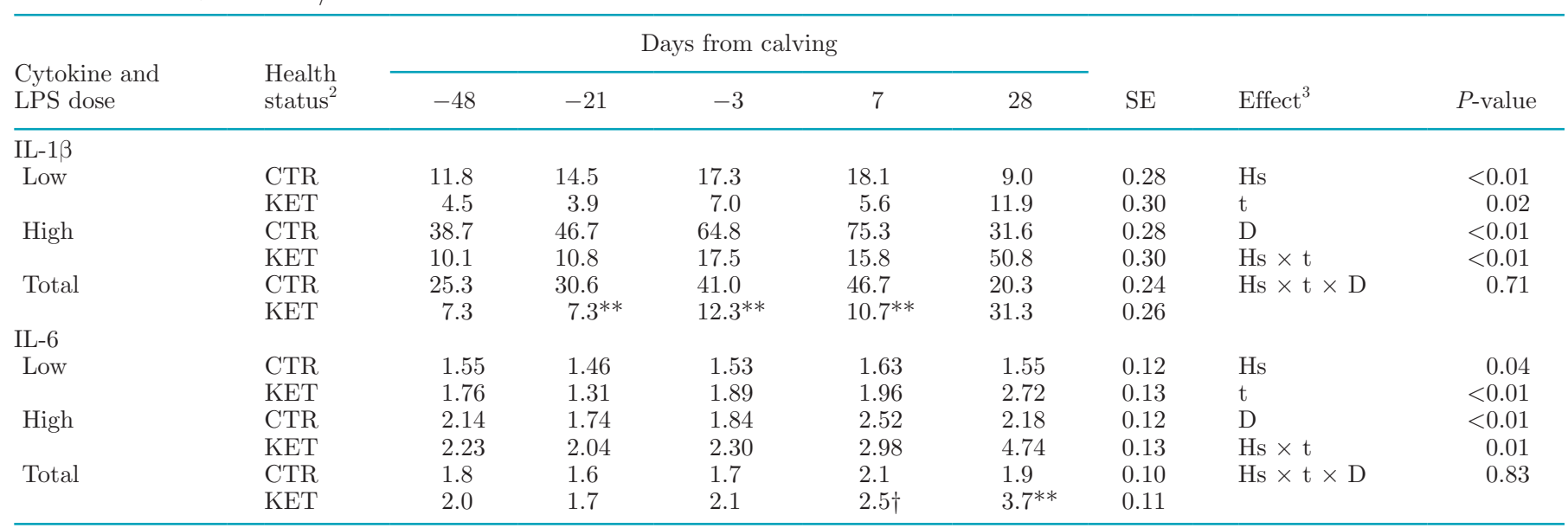

${ }^{1}$ Values are expressed as fold change with respect to baseline.

${ }^{2} \mathrm{CTR}=$ control; KET $=$ subclinical ketosis $(\mathrm{BHB}$ levels $>1.4 \mathrm{mmol} / \mathrm{L})$.

${ }^{3} \mathrm{Hs}=$ health status (CTR or KET); $\mathrm{t}=$ time (days from calving); $\mathrm{D}=$ dose (low or high LPS).

$* * P<0.01 ; \dagger P<0.1$.

Glucose uptake by WBC increased after the WBA, and production of D-lactic acid and L-lactic acid also increased (Table 3). Glucose uptake by WBC was not different between groups, but lactate production was greater in the KET group than the CTR group ( $\mathrm{Hs}=$ 0.01 for L-lactic acid; Hs $\times \mathrm{t}<0.01$ for both D-lactic acid and L-lactic acid). The production of $\mathrm{NOx}, \mathrm{NO}_{2}$, and $\mathrm{NO}_{3}$ by WBC was not affected by the grouping (Supplemental File S7; https://doi.org/10.3168/jds .2019-16497).

IFNG Release Assay and CST. The production of IFNG (Figure 6a) in whole blood in response to PPD

Table 3. Fold changes of glucose and metabolites thereof in a whole-blood stimulation assay with a low or high dose of bacterial LPS in control dairy cows or cows with BHB levels $>1.4 \mathrm{mmol} / \mathrm{L}$ in the first month of lactation ${ }^{1}$

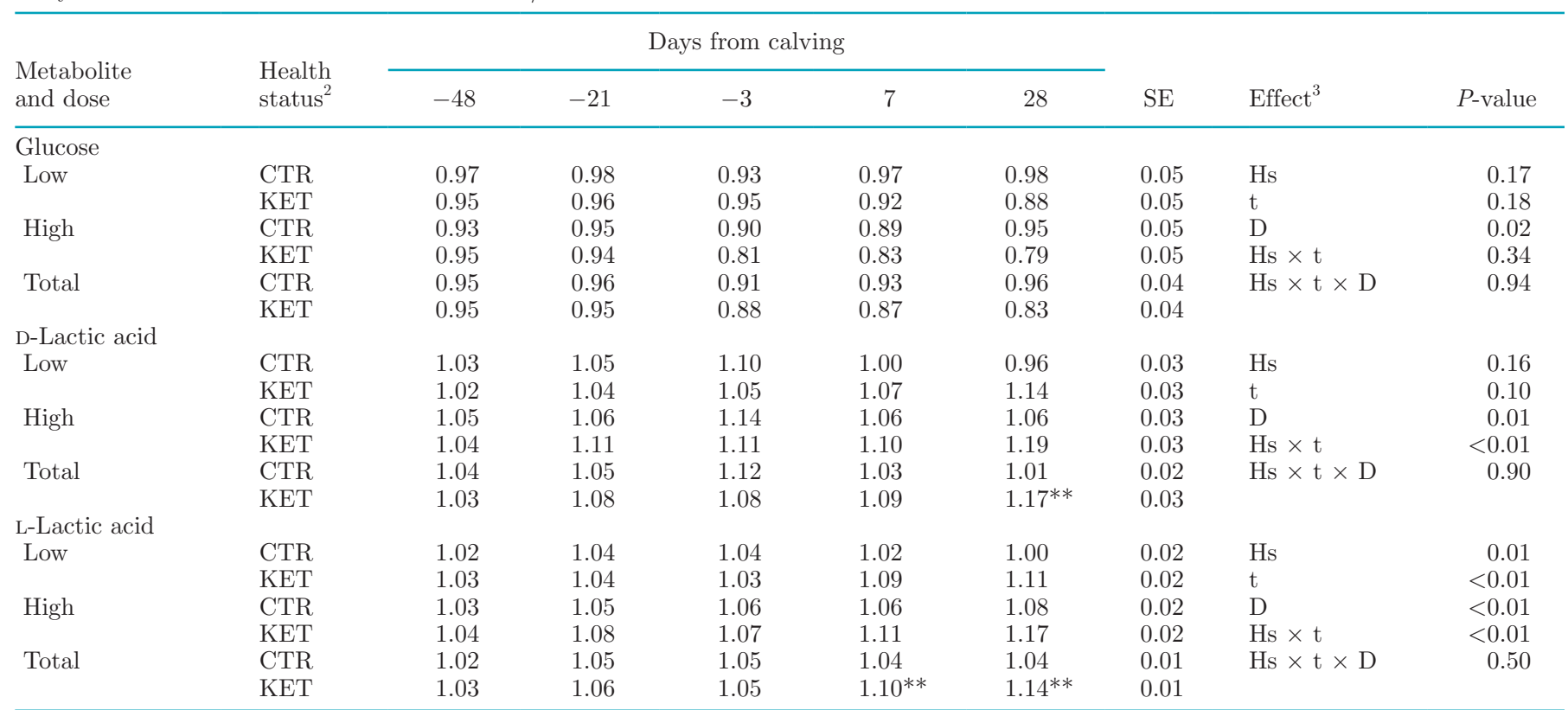

${ }^{1}$ Values are expressed as fold change with respect to baseline.

${ }^{2} \mathrm{CTR}=$ control; KET $=$ subclinical ketosis $($ BHB levels $>1.4 \mathrm{mmol} / \mathrm{L})$.

${ }^{3} \mathrm{Hs}=$ health status (CTR or KET); $\mathrm{t}=$ time (days from calving); $\mathrm{D}=$ dose (low or high LPS).

$* * P<0.01$. 

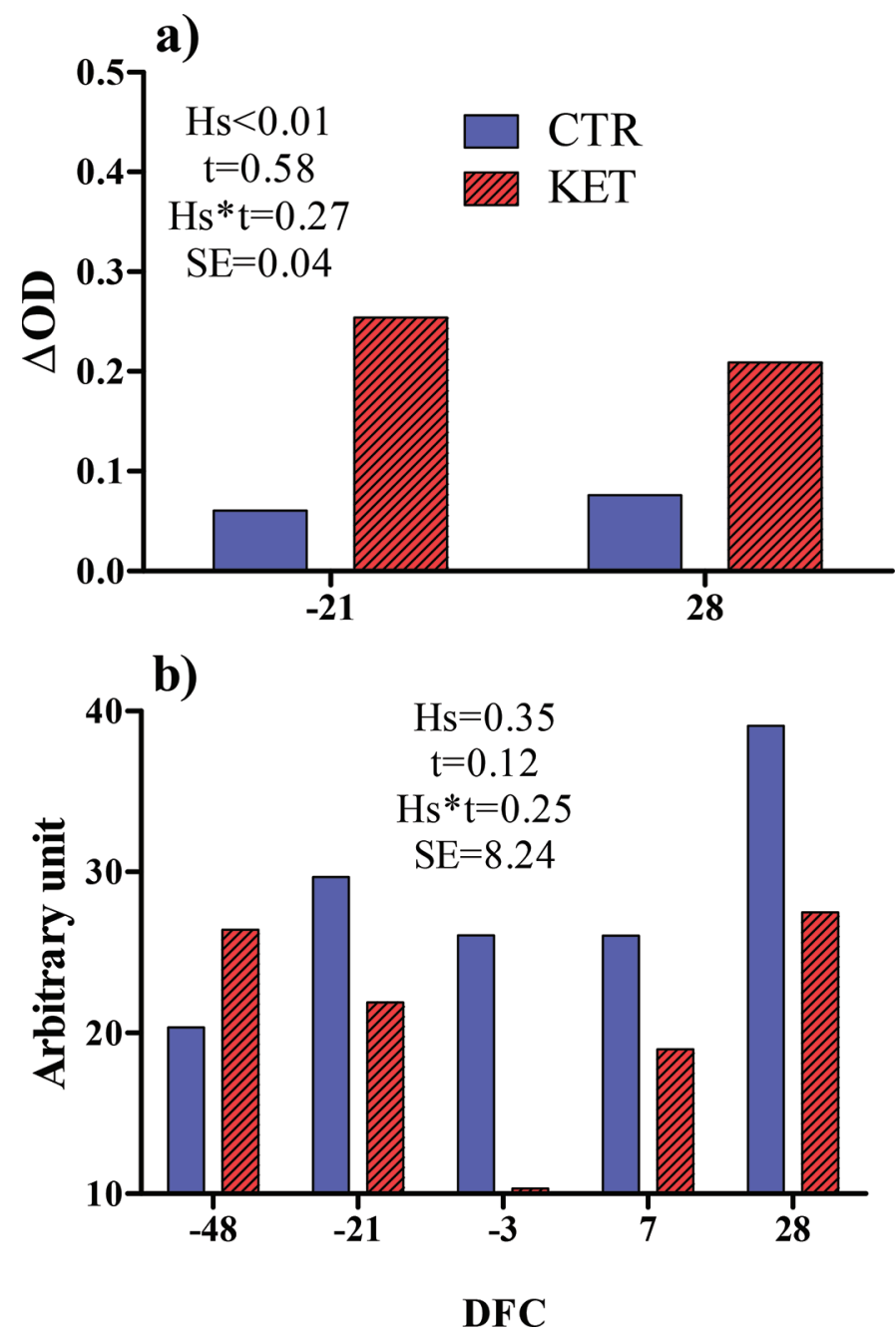

Figure 6. Optical density difference $(\Delta \mathrm{OD})$ between avian purified protein derivative-stimulated and control wells in the IFN- $\gamma$ (IFNG) release assay (a) and total peripheral response after the carrageenan skin test (CST; b) in control dairy cows (CTR) or cows with BHB $>1.4 \mathrm{mmol} / \mathrm{L}$ in the first month of lactation (KET). DFC is days from calving; $\mathrm{Hs}=$ health status effect; $\mathrm{t}=$ time effect; $\mathrm{Hs} \times \mathrm{t}=$ health status $\times$ time interaction effect; $\mathrm{SE}$ is the average standard error of the model.

was greater in the KET group than the CTR group (Hs $<0.01$ ). The response to CST (Figure 6b) was unaffected by SCK.

\section{DISCUSSION}

One limitation of our study was the small sample size, which was further complicated by the fact that 1 cow in the KET group had both retained placenta and milk fever before the BHB peak, whereas 2 other cows in the KET group had metritis and displaced abomasum that were diagnosed during the BHB peak. Previous works recognized that retained placenta and milk fever are potential direct causes of ketosis (Dohoo and Martin, 1984a), whereas metritis could indirectly contribute to ketosis because severe inflammation at calving is known to reduce feed intake (Dohoo and Martin, 1984a), inducing an increase in BHB (Bertoni et al., 2008). Mastitis was the only peripartum disease that consistently appeared $3 \mathrm{wk}$ after the BHB peak in our cows. Considering that 3 out of 6 cows had no clinical disease before the diagnosis of KET, we can conclude that SCK should not be considered a secondary disease, at least for $50 \%$ of the animals enrolled in our KET group.

\section{Possible Role of Placenta Prepartum in Alterations of Blood Parameters in Cows that Developed SCK Postpartum}

The higher levels of PIC (IL-1B and IL-6) detected in the blood of KET cows compared with CTR cows before calving are indicative of activation of the immune system during the dry period. This is supported by the parallel increase in the main markers of neutrophil and monocyte activation (myeloperoxidase and AOPP) and the higher concentrations of oxidant species related to their antimicrobial activity (ROMt and $\mathrm{NO}_{3}$ ) in the blood of KET cows versus CTR cows. Myeloperoxidase converts $\mathrm{NO}_{3}$ to a nitrating agent (Dedon and Tannenbaum, 2004) and generates hypochlorous acid, which could generate ROM within the respiratory burst (Faith et al., 2008). In contrast, AOPP are markers of protein oxidation triggered by these metabolites (Celi and Gabai, 2015). The main cause of such an activation of the immune system in all cows before SCK is not clear, but trends of immune parameters during the dry period are very similar to those observed in women affected by preeclampsia. According to Acauan Filho et al. (2016), "... preeclampsia is associated with the sequence of inadequate trophoblast invasion resulting in restricted spiral artery remodelling, low placental perfusion, placental ischemia, oxidative stress, and the consequent imbalance in the factors derived from placenta." Although very little is known about the pathophysiology of this disorder in women, and there are no reports of such a condition affecting dairy cows, the generalized dysfunction of the maternal endothelium during preeclampsia appears to be part of an exaggerated systemic inflammatory response that involves maternal leukocytes and PIC (Raghupathy, 2013). The increase in PIC and parameters related to leukocyte activation (myeloperoxidase and ROM) has been widely reported in preeclamptic women (Mori et al., 2014; Rocha-Penha et al., 2017; Cornelius, 2018) and suggests the development of a preeclamptic-like status during the dry period of ketotic cows in our study. This is supported by trends 
in other plasma parameters. The increased platelet concentrations found in our KET cows are consistent with the increased platelet aggregations reported during preeclampsia, as a consequence of vascular damage caused by active neutrophils during disease (Raghupathy, 2013). Higher levels of NOx in the blood of KET cows are also consistent with preeclampsia. Nitric oxide is a potent endogenous vasodilator that is produced by the enzyme nitric oxide synthase in the endothelium. Its release relaxes the blood vessel muscle layer, affecting the hemodynamic adaptation to pregnancy; it plays a pivotal role in preeclampsia pathogenesis (Acauan Filho et al., 2016).

Higher levels of GGT found in our KET animals during the dry period have been reported in dairy cows before SCK (Rodriguez-Jimenez et al., 2018) and suggest liver damage. In fact, GGT, as well as AST-GOT, is an enzyme involved in hepatic amino acid metabolism; GGT increases in the blood when liver damage occurs, a finding widely reported in preeclamptic women (Cornelius, 2018). Such an impaired hepatic metabolism likely accounts for the greater amounts of thiol groups found in the blood of KET cows throughout our study, because higher concentrations of thiol groups could be related to the reduced capacity of the liver to pick up free glutathione (the most abundant free thiol group in the blood) and sulfured amino acids from the blood (Guzman Barron, 1951).

Preeclampsia-like conditions in KET cows are further reflected by trends of plasma minerals. Lower level of zinc found in our KET cows have also been reported in preeclamptic women (Kim et al., 2012) and could account, in part, for the oxidative stress status typically reported during preeclampsia (Acauan Filho et al., 2016). Zinc is known to serve as a secondary antioxidant aiding the functioning of the superoxide dismutase enzymatic complex (Kim et al., 2012), and lower circulating levels of the mineral could lead to a lower scavenging capacity against free radicals. Furthermore, the lower levels of sodium, potassium, and phosphorus observed in our KET cows have been reported in women affected by preeclampsia (Ikechukwu et al., 2012; Kim et al., 2012; Ebenezer et al., 2017) and could be driven by renal dysfunction related to disease. Such an explanation is confirmed by the higher levels of creatinine found in the blood of KET cows during the entire experimental period and reported in preeclamptic women (Leeman et al., 2016). Creatinine is related to phosphocreatine utilization during normal muscular activity, and an increased blood concentration of this metabolite indicates impaired capacity of the kidneys to remove it (Zoccali et al., 2006).

Finally, the greater IFNG response of the peripheral blood leukocytes of KET cows to ex vivo stimulation with $M$. avium further supports the development of a preeclampsia-like status. Increased production of IFNG has been reported in decidual lymphocytes and choriodecidual cells of the placental trophoblast in preeclamptic pregnancies consequent to the reduced expression of the IFNG receptor R2 (Raghupathy, 2013). The production of IFNG by type 1 helper $\mathrm{T}$ cells has been proposed as one of the primary causes of the disease (Banerjee et al., 2005) and could provide a link between preeclampsia and SCK. Although a direct measurement of plasma IFNG is required to confirm such a hypothesis, we can speculate that the higher prepartal IFNG production measured in vitro in leukocytes from cows having a preeclamptic-like status could reflect their greater activity in vivo.

Higher IFNG concentrations could play a direct role in SCK induction after calving. Indeed, IFNG is known to inhibit expression of the peroxisome proliferationactivated receptor (PPAR)- $\gamma$ (Floyd and Stephens, 2002); PPAR- $\gamma$ plays an important role in adipocyte biology and is a main player in maintaining the insulin sensitivity of tissues, including adipose tissue (Waite et al., 2001; Choi et al., 2018). A link between insulin resistance and the risk of ketosis in dairy cows has already been suggested (Youssef and El-Ashker, 2017), consistent with the higher prepartal glucose concentrations detected in our KET cows compared with CTR cows, although previous studies failed to reveal any alteration of such a parameter before ketosis (Abuajamieh et al., 2016). Our study might also suggest a link between insulin resistance and the preeclampticlike status affecting our KET cows before calving, consistent with the reported hyperglycemia that affects preeclamptic women (Kaaja, 2011; Sacks et al., 2015). On the other hand, the prepartal increase of NEFA and $\mathrm{BHB}$ at nonpathological levels found in our cows is well known before ketosis (Zhang et al., 2016). The concentration of NEFA at -14 DFC has been suggested as a predictive biomarker of disease (Chapinal et al., 2011). Increased plasma concentrations of NEFA reflect the mobilization of lipid sources, whereas BHB is released in the blood when liver oxidation is impaired by a fatty acid overload (Herdt, 2000). In this scenario, IFNGdriven PPAR- $\gamma$ inhibition could be pivotal to boosting the onset of SCK after calving. Decreased lipogenesis and increased lipolysis occur when PPAR- $\gamma$ is inhibited (Waite et al., 2001). This may be conducive to a greater mobilization of NEFA for energy metabolism.

Preeclampsia in women is associated with obesity (Roberts et al., 2011), and several of the changes of the measured parameters also appear to be associated with fat cow syndrome (Morrow, 1976). None of the cows in the study would have been considered obese, and no differences in the BCS were detected between 
KET cows and CTR cows, in agreement with previous results that evaluated body condition before ketosis (Rodriguez-Jimenez et al., 2018). In humans, greater production of adipokines has been associated with preeclampsia (Haugen et al., 2006). Disruptive production of adipokines in preeclampsia cases is associated with visceral adipose tissue (Huda et al., 2017). In non-obese dairy cows, large variations in visceral adipose tissue are not visible by using BCS (Drackley et al., 2014). Thus, it is possible that ketotic cows in our study had greater production of adipokines by visceral adipose tissue compared with control animals.

It is important to emphasize that, despite several similarities with a preeclampsia model, our data do not support a hypothesis that cows with ketosis had preeclampsia. None of the cows enrolled in this study were diagnosed with preeclampsia. Typical symptoms of preeclampsia, including rapid weight gain, proteinuria, edema, increased abortion rates, or reduced newborn calf weights, were not detected. Thus, we certainly cannot conclude that our cows experienced preeclampsia; however, because of the central role of the placenta in preeclampsia (Roberts and Escudero, 2012), we can speculate that a subclinical dysfunction of the placenta might have been an associated cause of the observed changes in measured parameters in the plasma prepartum, with ensuing SCK postpartum.

\section{Cows with SCK Have Impaired Feeding Behavior}

The onset of SCK is related to an impairment of feeding behavior, as suggested by the reduced DMI and rumination time detected in our study after calving. Low feed intake (Zhang et al., 2016) and an average reduction in rumination time up to $25 \mathrm{~min} / \mathrm{d}$ are consistently reported in dairy cows during the week in which ketosis is diagnosed (Abuajamieh et al., 2016). Recent studies have also highlighted the alterations in these parameters before calving (Kaufman et al., 2016; Rodriguez-Jimenez et al., 2018). Such an impairment in feeding behaviors in ketotic cows could arise from the strong anorexic effect of the combined increase of PIC, NEFA, and BHB (Bertoni et al., 2008; Allen et al., 2009) as well as from the insulin resistance-like status that occurs before calving (Youssef and El-Ashker, 2017), that could be involved in the reduction of feed intake. This could be also caused by changes in rumen fermentation. Wang et al. (2012) reported a reduction of propionate-forming bacteria (Megasphaera elsdenii and Selenomonas ruminantium) and an increase in lactateproducing bacteria (Streptococcus bovis), reflected in an increased lactate concentration and reduced production of VFA in the rumen of cows affected by acute ketosis (blood BHB concentration $>3 \mathrm{mmol} / \mathrm{L}$ ). Unfortunately, rumen samples were collected during the fourth week of lactation in our study; most of our animals had BHB peaks during the first and second weeks from calving, making it difficult to correlate any rumen alterations with ketosis. Furthermore, the mild ketosis detected in our animals (blood BHB concentration $>1.4 \mathrm{mmol} / \mathrm{L}$ ) could account for the lack of any effect on VFA and lactate.

The reduced DMI and rumination time in KET cows, together with the increased energy demand related to the activation of their immune system during the dry period, could have worsened the physiological negative energy balance condition after calving (Soriani et al., 2012; Osorio et al., 2014). This could account for the depression in milk yield and milk fat and protein outputs detected in our study with SCK, consistent with milk losses $>350 \mathrm{~kg} /$ cow in the whole lactation period reported previously (Zhang et al., 2016). The lower glucose levels detected in our KET versus CTR cows postpartum could be caused by several factors, including a higher utilization of glucose by immune cells but also an impaired glucogenic capacity of the liver (Loor et al., 2007).

Lower glucose levels in the blood of our KET cows could had triggered a marked shift to other energy sources. This is consistent with the stepwise increase in both NEFA and BHB, which suggests a major role of lipid sources as energy suppliers, as has been widely reported in ketotic cows during early lactation (Duffield, 2000). On the other hand, the lower postpartal urea concentrations detected in the blood of our KET cows contrast with the findings of Rodriguez-Jimenez et al. (2018). They also reflects a less marked contribution of muscle tissues in supplying the energy deficit in KET cows versus CTR cows, because the blood urea partially arises from the deamination of amino acids. Nevertheless, detection of a similar decrease in milk urea levels suggests that decreased feed intake of KET cows is the main cause in the alteration of this parameter (Bertoni et al., 2008).

\section{Subclinical Ketosis Is Associated with Inflammatory- Like Conditions Postpartum}

The presence of an inflammatory-like status appears to be a physiological condition during the transition period in dairy cows (Bionaz et al., 2007; Bertoni et al., 2008). When inflammation develops, the liver shifts its anabolic priorities and the plasma trends of the APP reflect the severity of the phenomenon (Castell et al., 1989). Plasma concentrations of positive APP, such as haptoglobin, ceruloplasmin, and serum amyloid $\alpha$, increase (Ceciliani et al., 2012), but concentrations of other typical proteins labeled as negative APP, such as 
albumin, paraoxonase, lipoproteins, and retinol-binding protein, typically decrease (Bionaz et al., 2007; Trevisi et al., 2012).

The lack of any prepartal difference in positive APP, together with the greater paraoxonase concentrations of KET cows versus CTR cows, suggests a lack of an acute-phase reaction, despite the higher level of PIC during this phase. Conversely, the higher levels of positive APP and the lower levels of retinol reflect a more marked inflammatory status in KET animals after calving, although no differences were detected for other negative APP. Lower levels of plasma zinc could further support the increased inflammatory conditions occurring in KET cows after calving, because this mineral is sequestered by the liver from the blood during an acute-phase response (Bertoni and Trevisi, 2013). Furthermore, augmented postpartal concentrations of GGT and AST-GOT found in our KET cows reflect the results of Rodriguez-Jimenez et al. (2018), indicating that liver damage is aggravated by delivery. This is further confirmed by the greater bilirubin concentrations observed in the same period. Bilirubin results from the degradation of red blood cells, and its clearance is related to the activity of liver enzymes (RodriguezJimenez et al., 2018).

\section{An Attenuated Response of WBC to LPS and Possible Immunosuppression Are Found in Postpartum Ketotic Cows}

The WBC produced less IL-1B in response to LPS in KET cows compared with CTR cows at $21 \mathrm{~d}$ before calving, and this persisted for the first week postpartum. The production of IL-6 in response to LPS did not differ between KET and CTR cows during the same period, but the WBC production of IL-6 after LPS stimulation was greater in KET cows than in CTR cows after SCK developed, along with increased production of lactate. Interleukin-1B is a well-known PIC, and IL-6 is known to have both pro- and antiinflammatory activities. Lactate produced by immune cells has been reported to lower their motility, killing capability, and effector functions, including the production of PIC (Fischer et al., 2007; Goetze et al., 2011 cited by Zhang et al., 2016). Such altered responses in the WBC are consistent with their shift from a pro- to an anti-inflammatory response, driven by altered gene expression at the level of the liver with SCK, although the effect found on IL-1B production before SCK suggests that another mechanism contributes to such an alteration. As indicated above, ketotic animals in our study had preeclampsia-like conditions; interestingly, the condition of preeclampsia is known to weaken the body defenses (Cornelius, 2018). If such effects oc- curred in the early dry period (or even before), they could have allowed bacterial cell components to enter the organism (Trevisi et al., 2018), challenging immune cells and inducing a condition of endotoxin tolerance in them. This is a protective mechanism against overexuberant inflammation that could have developed when the WBC faced an endotoxin challenge. This response consists of decreased production of PIC and upregulation of anti-inflammatory genes, which would trigger a transient unresponsive state against further challenges with endotoxins (Biswas and Lopez-Collazo, 2009).

A higher concentration of circulating WBC was expected in KET cows compared with CTR cows during the entire experimental period. This expectation was based on activation of the immune system during the dry period (higher levels of PIC, myeloperoxidase, ROMt, AOPP, and $\mathrm{NO}_{3}$ and greater IFNG production in vitro) and more marked inflammatory conditions present after calving (reflected in positive APP and liver function biomarker trends). Increased numbers of circulating neutrophils and monocytes were, however, only detected in KET cows in the late postcalving period, when the metabolic status related to SCK was overcome, suggesting that WBC viability was reduced during disease. This could be explained by the negative effect induced from the metabolic asset related to SCK status on WBC viability. Leukocytes use glucose more efficiently than alternative energy sources (Sordillo, 2016), and when the availability of glucose decreases, as occurred in our KET cows after calving, the proliferation, differentiation, and viability of macrophages and polymorphonuclear cells also decreases, as has been reported by several researchers (Barghouthi et al., 1995; Gamelli et al., 1996).

High concentrations of NEFA and BHB, such as those detected in KET cows throughout our study, can directly affect WBC functions. $\beta$-Hydroxybutyrate cannot be utilized as an energy source in WBC (Targowski and Klucinski, 1983; Hoeben et al., 1997; Suriyasathaporn et al., 1999), and NEFA increase apoptosis and necrosis in macrophages and polymorphonuclear cells through the stimulation of their respiratory burst activity (Scalia et al., 2006). This could account for the higher ROMt and AOPP concentrations found in KET cows in our experiment. Furthermore, NEFA increase the production of PIC and IFN in lymphocytes (Hughes and Pinder, 2000); thus, the higher NEFA concentrations detected in KET cows before calving could account, in part, for the higher PIC and greater IFNG response by WBC after ex vivo stimulation. Finally, the higher level of lactate in the blood of ketotic cows versus control cows in early lactation could have impaired immune cell functions (Fischer et al., 2007; Goetze et al., 2011 cited by Zhang et al., 2016). Such 
an impairment could account for the numerically higher incidence of udder diseases found in ketotic cows, which has been widely reported in previous works (Duffield, 2000). Mastitis was the only peripartum disease that showed a tendency for an Hs effect in our experiment, and both cases could plausibly be associated with SCK because they appeared 3 wk after the BHB peak.

\section{CONCLUSIONS}

In our study, the occurrence of SCK was preceded by a preeclampsia-like status during the dry period; the condition included high oxidative stress, high levels of PIC and nitrates, possible reduced renal function, liver damage, reduced blood mineral concentrations, and an activated immune system. An increased production of IFNG by leukocytes in vitro was also detected, which may have affected PPAR- $\gamma$ expression and, thus, insulin sensitivity. The latter might explain the larger plasma concentrations of NEFA and BHB observed in KET cows prepartum. The anorexic power exerted by PIC, NEFA, and BHB and the high circulating glucose levels could have reduced the DMI around the time of calving. Furthermore, the increased energy requirements related to activation of the immune system in the dry period could have contributed to worsening of the negative energy balance condition in early lactation. Such a condition induced severe milk yield losses and boosted the mobilization of lipid sources. These conditions appear to have influenced the greater acute-phase response after calving, which compromised liver function to some degree. Our data indicate a possible endotoxin tolerance of WBC in KET cows that could account for the reduced production of PIC and increased production of anti-inflammatory mediators, such as lactate, by WBC under LPS stimulation. Overall, our data suggest a role for the immune system, which may be associated with a still-unclear placental role (or adipose tissue role), during the dry period in promoting SCK in the early postpartum period. The associations identified here in a small number of cows in one herd should be further investigated. A larger, in-depth study is required to explore the alterations in pathways regulating energy metabolism before onset of SCK, as well as the role of the immune system in such alterations. It would fully elucidate the real contribution of IFNG and other cytokines to the disease onset.

\section{ACKNOWLEDGMENTS}

This work was conducted in the framework of projects supported by CREI (Romeo and Enrica Invernizzi Research Center of the Università Cattolica del S. Cuore) funded by the "Fondazione Romeo ed Enrica
Invernizzi," Milan, Italy. The authors convey sincere thanks and appreciation to Gianfranco Gabai (Department of Comparative Biomedicine and Food Science, University of Padova, Legnaro, Italy) for valuable suggestions provided during writing.

\section{REFERENCES}

Abuajamieh, M., S. K. Kvidera, M. V. S. Fernandez, A. Nayeri, N. C. Upah, E. A. Nolan, S. M. Lei, J. M. DeFrain, H. B. Green, K. M. Schoenberg, W. E. Trout, and L. H. Baumgard. 2016. Inflammatory biomarkers are associated with ketosis in periparturient Holstein cows. Res. Vet. Sci. 109:81-85. https://doi.org/10.1016/ j.rvsc.2016.09.015.

Acauan Filho, B. J., B. E. Pinheiro da Costa, P. B. Ogando, M. C. Vieira, I. C. Antonello, and C. E. Poli-de-Figueiredo. 2016. Serum nitrate and NOx levels in preeclampsia are higher than in normal pregnancy. Hypertens. Pregnancy 35:226-233. https://doi.org/10 .3109/10641955.2016.1139718.

Agricultural Development and Advisory Service. 1986. Condition scoring of dairy cows. Publication 612. Ministry of Agriculture, Fisheries Food (PubI.). Lion House, Alnwick, Northumberland NE66 2PF, UK.

Akbar, H., F. Batistel, J. K. Drackley, and J. J. Loor. 2015. Alterations in hepatic FGF21, co-regulated genes, and upstream metabolic genes in response to nutrition, ketosis and inflammation in peripartal holstein cows. PLoS One 10:e0139963. https://doi.org/ 10.1371/journal.pone.0139963.

Allen, M. S., B. J. Bradford, and M. Oba. 2009. Invited review: the hepatic oxidation theory of the control of feed intake and its application to ruminants. J. Anim. Sci. 87:3317-3334. https://doi.org/ $10.2527 /$ jas. $2009-1779$

Banerjee, S., A. Smallwood, J. Moorhead, A. E. Chambers, A. Papageorghiou, S. Campbell, and K. Nicolaides. 2005. Placental expression of interferon-gamma (IFN-gamma) and its receptor IFN-gamma R2 fail to switch from early hypoxic to late normotensive development in preeclampsia. J. Clin. Endocrinol. Metab. 90:944-952. https://doi.org/10.1210/jc.2004-1113.

Barghouthi, S., K. D. Everett, and D. P. Speert. 1995. Nonopsonic phagocytosis of Pseudomonas aeruginosa requires facilitated transport of D-glucose by macrophages. J. Immunol. 154:3420-3428.

Bertoni, G., and E. Trevisi. 2013. Use of the liver activity index and other metabolic variables in the assessment of metabolic health in dairy herds. Vet. Clin. North Am. Food Anim. Pract. 29:413-431. https://doi.org/10.1016/j.cvfa.2013.04.004.

Bertoni, G., E. Trevisi, X. Han, and M. Bionaz. 2008. Effects of inflammatory conditions on liver activity in puerperium period and consequences for performance in dairy cows. J. Dairy Sci. 91:3300 3310. https://doi.org/10.3168/jds.2008-0995.

Bionaz, M., E. Trevisi, L. Calamari, F. Librandi, A. Ferrari, and G. Bertoni. 2007. Plasma paraoxonase, health, inflammatory conditions, and liver function in transition dairy cows. J. Dairy Sci. 90:1740-1750. https://doi.org/10.3168/jds.2006-445.

Biswas, S. K., and E. Lopez-Collazo. 2009. Endotoxin tolerance: New mechanisms, molecules and clinical significance. Trends Immunol. 30:475-487. https://doi.org/10.1016/j.it.2009.07.009.

Bradley, P. P., D. A. Priebat, R. D. Christensen, and G. Rothsein. 1982. Measurement of cutaneous inflammation: estimation of neutrophil content with an enzyme marker. J. Invest. Dermatol. 78:206-209. https://doi.org/10.1111/1523-1747.ep12506462.

Calamari, L., A. Ferrari, A. Minuti, and E. Trevisi. 2016. Assessment of the main plasma parameters included in a metabolic profile of dairy cow based on Fourier Transform mid-infrared spectroscopy: preliminary results. BMC Vet. Res. 12:4. https://doi.org/10.1186/ s12917-015-0621-4.

Calamari, L., F. Petrera, and G. Bertin. 2010. Effects of either sodium selenite or Se yeast (Sc CNCM I-3060) supplementation on selenium status and milk characteristics in dairy cows. Livest. Sci. 128:154-165. https://doi.org/10.1016/j.livsci.2009.12.005. 
Castell, J. V., M. J. Gómez-Lechón, M. David, T. Andus, T. Geiger, R. Trullenque, R. Fabra, and P. C. Heinrich. 1989. Interleukin-6 is the major regulator of acute phase protein synthesis in adult human hepatocytes. FEBS Lett. 242:237-239.

Ceciliani, F., J. J. Ceron, P. D. Eckersall, and H. Sauerwein. 2012. Acute phase proteins in ruminants. J. Proteomics 75:4207-4231. https://doi.org/10.1016/j.jprot.2012.04.004.

Celi, P., and G. Gabai. 2015. Oxidant/antioxidant balance in animal nutrition and health: the role of protein oxidation. Front. Vet. Sci. 2:48. https://doi.org/10.3389/fvets.2015.00048.

Chapinal, N., M. Carson, T. F. Duffield, M. Capel, S. Godden, M. Overton, J. E. P. Santos, and S. J. LeBlanc. 2011. The association of serum metabolites with clinical disease during the transition period. J. Dairy Sci. 94:4897-4903. https://doi.org/10.3168/jds $.2010-4075$.

Chessa, S., O. Bulgari, R. Rizzi, L. Calamari, P. Bani, S. Biffani, and A. M. Caroli. 2014. Selection for milk coagulation properties predicted by Fourier transform infrared spectroscopy in the Italian Holstein-Friesian breed. J. Dairy Sci. 97:4512-4521. https://doi .org/10.3168/jds.2013-7798.

Choi, S. H., S. S. Chung, and K. S. Park. 2018. Re-highlighting the action of PPAR $\gamma$ in treating metabolic diseases. F1000Res. 7:1127. https://doi.org/10.12688/f1000research.14136.1.

Cornelius, D. C. 2018. Preeclampsia: from inflammation to immunoregulation. Clin. Med. Insights Blood Disord. 11:X17752325. https: //doi.org/10.1177/1179545X17752325.

Dedon, P. C., and S. R. Tannenbaum. 2004. Reactive nitrogen species in the chemical biology of inflammation. Arch. Biochem. Biophys. 423:12-22. https://doi.org/10.1016/j.abb.2003.12.017.

Dohoo, I. R., and S. W. Martin. 1984a. Subclinical ketosis: Prevalence and associations with production and disease. Can. J. Comp. Med. $48: 1-5$.

Drackley, J. K. 1999. Biology of dairy cows during the transition period: the final frontier? J. Dairy Sci. 82:2259-2273. https://doi .org/10.3168/jds.S0022-0302(99)75474-3.

Drackley, J. K., R. L. Wallace, D. E. Graugnard, J. Vasquez, B. F. Richards, and J. J. Loor. 2014. Visceral adipose tissue mass in nonlactating dairy cows fed diets differing in energy density(1). J. Dairy Sci. 97:3420-3430. https://doi.org/10.3168/jds.2014-8014.

Duffield, T. F. 2000. Subclinical ketosis in lactating dairy cattle. Vet. Clin. North Am. Food Anim. Pract. 16:231-253. https://doi.org/ 10.1016/S0749-0720(15)30103-1.

Ebenezer, O., R. Darkwa, C. Djagbletey, G. Antwi-Boasiako, D. S. Aryee, and A. Alexander. 2017. Serum sodium and potassium levels in preeclampsia: A case-control study in a large tertiary hospital in Ghana. Cogent Med. 4:1. https://doi.org/10.1080/2331205X 2017.1376898

Faith, M., A. Sukumaran, A. B. Pulimood, and M. Jacob. 2008. How reliable an indicator of inflammation is myeloperoxidase activity? Clin. Chim. Acta 396:23-25. https://doi.org/10.1016/j.cca.2008.06 .016 .

Faul, F., E. Erdfelder, A.-G. Lang, and A. Buchner. 2007. G*Power 3: A flexible statistical power analysis program for the social, behavioral, and biomedical sciences. Behav. Res. Methods 39:175-191.

Fischer, K., P. Hoffmann, S. Voelkl, N. Meidenbauer, J. Ammer, M. Edinger, E. Gottfried, S. Schwarz, G. Rothe, S. Hoves, K. Renner, B. Timischl, A. Mackensen, L. Kunz-Schughart, R. Andreesen, S. W. Krause, and M. Kreutz. 2007. Inhibitory effect of tumor cellderived lactic acid on human T cells. Blood https://doi.org/10 .1182/blood-2006-07-035972.

Floyd, Z. E., and J. M. Stephens. 2002. Interferon- $\gamma$-mediated activation and ubiquitin-proteasome-dependent degradation of PPAR $\gamma$ in adipocytes. J. Biol. Chem. 277:4062-4068. https://doi.org/10 .1074/jbc.M108473200.

Gamelli, R. L., H. Liu, L. K. He, and C. A. Hofmann. 1996. Augmentations of glucose uptake and glucose transporter-1 in macrophages following thermal injury and sepsis in mice. J. Leukoc. Biol. 59:639-647.

Goetze, K., S. Walenta, M. Ksiazkiewicz, L. A. Kunz-Schughart, and W. Mueller-Klieser. 2011. Lactate enhances motility of tumor cells and inhibits monocyte migration and cytokine release. Int. J. Oncol. https://doi.org/10.3892/ijo.2011.1055.

Gordon, J. L., S. J. LeBlanc, and T. F. Duffield. 2013. Ketosis treatment in lactating dairy cattle. Vet. Clin. North Am. Food Anim. Pract. 29:433-445. https://doi.org/10.1016/j.cvfa.2013.03.001.

Guzman Barron, E. S. 1951. Thiol groups of biological importance. Pages 201-266 in Advances in Enzymology and Related Areas of Molecular Biology. Vol. 11. F. F. Nord, ed. Interscience Publishers Inc., New York, NY.

Hanasand, M., R. Omdal, K. B. Norheim, L. G. Gøransson, C. Brede, and G. Jonsson. 2012. Improved detection of advanced oxidation protein products in plasma. Clin. Chim. Acta 413:901-906. https: //doi.org/10.1016/j.cca.2012.01.038.

Haugen, F., T. Ranheim, N. K. Harsem, E. Lips, A. C. Staff, and C. A. Drevon. 2006. Increased plasma levels of adipokines in preeclampsia: relationship to placenta and adipose tissue gene expression. Am. J. Physiol. Endocrinol. Metab. 290:E326-E333. https://doi .org/10.1152/ajpendo.00020.2005.

Herdt, T. H. 2000. Ruminant adaptation to negative energy balance. Influences on the etiology of ketosis and fatty liver. Vet. Clin. North Am. Food Anim. Pract. 16:215-230. https://doi.org/10 .1016/S0749-0720(15)30102-X.

Herdt, T. H., J. B. Stevens, W. G. Olson, and V. Larson. 1981. Blood concentrations of beta hydroxybutyrate in clinically normal Holstein-Friesian herds and in those with a high prevalence of clinical ketosis. Am. J. Vet. Res. 42:503-506.

Hoeben, D., R. Heyneman, and C. Burvenich. 1997. Elevated levels of $\beta$-hydroxybutyric acid in periparturient cows and in vitro effect on respiratory burst activity of bovine neutrophils. Vet. Immunol. Immunopathol. 58:165-170. https://doi.org/10.1016/S0165 $-2427(97) 00031-7$.

Huda, S. S., F. Jordan, J. Bray, G. Love, R. Payne, N. Sattar, and D. J. Freeman. 2017. Visceral adipose tissue activated macrophage content and inflammatory adipokine secretion is higher in pre-eclampsia than in healthy pregnancies. Clin. Sci. (Lond.) 131:1529 1540. https://doi.org/10.1042/CS20160832.

Hughes, D. A., and A. C. Pinder. 2000. N-3 polyunsaturated fatty acids inhibit the antigen-presenting function of human monocytes. Am. J. Clin. Nutr. 71:357S-360S.

Ikechukwu, I. C., O. I. Ojareva, A. J. Ibhagbemien, O. F. Okhoretor, O. B. Oluwatomi, O. S. Akhalufo, A. T. Oluwagbenga, and M. N. Chigaekwu. 2012. Blood lead, calcium, and phosphorus in women with preeclampsia in Edo state, Nigeria. Arch. Environ. Occup. Health 67:163-169. https://doi.org/10.1080/19338244 .2011.619212.

Ingvartsen, K. L. 2006. Feeding- and management-related diseases in the transition cow: physiological adaptations around calving and strategies to reduce feeding-related diseases. Anim. Feed Sci. Technol. 126:175-213. https://doi.org/10.1016/j.anifeedsci.2005 .08 .003 .

Ingvartsen, K. L., and K. Moyes. 2013. Nutrition, immune function and health of dairy cattle. Animal 7:112-122. https://doi.org/10 $.1017 /$ S175173111200170X.

Ireland-Perry, R. L., and C. C. Stallings. 1993. Fecal consistency as related to dietary composition in lactating Holstein cows. J. Dairy Sci. 76:1074-1082.

Jacometo, C. B., J. S. Osorio, M. Socha, M. N. Corrêa, F. PiccioliCapelli, E. Trevisi, and J. J. Loor. 2015. Maternal consumption of organic trace minerals (4-Plex) alters calf systemic and neutrophil mRNA and microRNA indicators of inflammation and oxidative stress. J. Dairy Sci. 98:7717-7729. https://doi.org/10.3168/jds .2015-9359.

Jahan, N., A. Minuti, and E. Trevisi. 2015. Assessment of immune response in periparturient dairy cows using ex vivo whole blood stimulation assay with lipopolysaccharides and carrageenan skin test. Vet. Immunol. Immunopathol. 165:119-126. https://doi.org/ 10.1016/j.vetimm.2015.04.003.

Kaaja, R. 2011. Vascular complications in diabetic pregnancy. Thromb. Res. 127:S53-S55. https://doi.org/10.1016/S0049-3848(11)70015 -9 . 
Kaufman, E. I., S. J. LeBlanc, B. W. McBride, T. F. Duffield, and T. J. DeVries. 2016. Association of rumination time with subclinical ketosis in transition dairy cows. J. Dairy Sci. 99:5604-5618. https: //doi.org/10.3168/jds.2015-10509.

Kim, J., Y. J. Kim, R. Lee, J. H. Moon, and I. Jo. 2012. Serum levels of zinc, calcium, and iron are associated with the risk of preeclampsia in pregnant women. Nutr. Res. 32:764-769. https://doi .org/10.1016/j.nutres.2012.09.007.

Lacetera, N., D. Scalia, O. Franci, U. Bernabucci, B. Ronchi, and A. Nardone. 2004. Short communication: Effects of nonesterified fatty acids on lymphocyte function in dairy heifers. J. Dairy Sci 87:1012-1014. https://doi.org/10.3168/jds.S0022-0302(04)73246 -4 .

Lauzi, S., D. Pasotto, M. Aamadori, I. L. Archetti, G. Poli, and L. Bonizzi. 2000. Evaluation of the specificity of the $\gamma$-interferon test in Italian bovine tuberculosis-free herds. Vet. J. 160:17-24. https:/ /doi.org/10.1053/tvjl.1999.0444.

Leeman, L., L. T. Dreesang, and F. Patricia. 2016. Hypertensive disorders of pregnancy. Am. Fam. Physician 93:121-127.

Littell, R. C., P. R. Henry, and C. B. Ammerman. 1998. Statistical analysis of repeated measures data using SAS procedures. J. Anim. Sci. 76:1216. https://doi.org/10.2527/1998.7641216x.

Loor, J. J., R. E. Everts, M. Bionaz, H. M. Dann, D. E. Morin, R. Oliveira, S. L. Rodriguez-Zas, J. K. Drackley, and H. A. Lewin. 2007. Nutrition-induced ketosis alters metabolic and signaling gene networks in liver of periparturient dairy cows. Physiol. Genomics 32:105-116. https://doi.org/10.1152/physiolgenomics.00188.2007.

Minuti, A., S. Ahmed, E. Trevisi, F. Piccioli-Cappelli, G. Bertoni, N. Jahan, and P. Bani. 2014. Experimental acute rumen acidosis in sheep: consequences on clinical, rumen, and gastrointestinal permeability conditions and blood chemistry. J. Anim. Sci. 92:39663977. https://doi.org/10.2527/jas.2014-7594.

Mori, T., K. Watanabe, A. Iwasaki, C. Kimura, H. Matsushita, K. Shinohara, and A. Wakatsuki. 2014. Differences in vascular reactivity between pregnant women with chronic hypertension and preeclampsia. Hypertens. Res. 37:145-150. https://doi.org/10 $.1038 /$ hr.2013.131.

Morrow, D. A. 1976. Fat cow syndrome. J. Dairy Sci. 59:1625-1629. https://doi.org/10.3168/jds.S0022-0302(76)84415-3.

Osorio, J. S., E. Trevisi, P. Ji, J. K. Drackley, D. Luchini, G. Bertoni, and J. J. Loor. 2014. Biomarkers of inflammation, metabolism, and oxidative stress in blood, liver, and milk reveal a better immunometabolic status in peripartal cows supplemented with Smartamine M or MetaSmart. J. Dairy Sci. 97:7437-7450. https://doi .org/10.3168/jds.2013-7679.

Raghupathy, R. 2013. Cytokines as key players in the pathophysiology of preeclampsia. Med. Princ. Pract. 22:8-19. https://doi.org/10 $.1159 / 000354200$.

Roberts, J. M., and C. Escudero. 2012. The placenta in preeclampsia. Pregnancy Hypertens. 2:72-83. https://doi.org/10.1016/j.preghy .2012.01.001

Roberts, J. M., L. M. Bodnar, T. E. Patrick, and R. W. Powers. 2011. The role of obesity in preeclampsia. Pregnancy Hypertens. 1:6-16. https://doi.org/10.1016/j.preghy.2010.10.013.

Rocha-Penha, L., M. Caldeira-Dias, J. E. Tanus-Santos, R. de Carvalho Cavalli, and V. C. Sandrim. 2017. Myeloperoxidase in hypertensive disorders of pregnancy and its relation with nitric oxide. Hypertension 69:1173-1180. https://doi.org/10.1161/ HYPERTENSIONAHA.116.08854.

Rodriguez-Jimenez, S., K. J. Haerr, E. Trevisi, J. J. Loor, F. C. Cardoso, and J. S. Osorio. 2018. Prepartal standing behavior as a parameter for early detection of postpartal subclinical ketosis associated with inflammation and liver function biomarkers in peripartal dairy cows. J. Dairy Sci. 101:8224-8235. https://doi.org/10 $.3168 /$ jds.2017-14254.

Røntved, C. M., J. B. Andersen, J. Dernfalk, and K. L. Ingvartsen. 2005. Effects of diet energy density and milking frequency in early lactation on tumor necrosis factor-alpha responsiveness in dairy cows. Vet. Immunol. Immunopathol. 104:171-181. https://doi.org/ $10.1016 /$ j.vetimm.2004.11.001.

Sacks, D. A., M. H. Black, X. Li, M. N. Montoro, and J. M. Lawrence. 2015. Adverse pregnancy outcomes using the international association of the diabetes and pregnancy study groups criteria: Glycemic thresholds and associated risks. Obstet. Gynecol. 126:67-73. https: //doi.org/10.1097/AOG.0000000000000865.

Scalia, D., N. Lacetera, U. Bernabucci, K. Demeyere, L. Duchateau, and C. Burvenich. 2006. In vitro effects of nonesterified fatty acids on bovine neutrophils oxidative burst and viability. J. Dairy Sci. 89:147-154. https://doi.org/10.3168/jds.S0022-0302(06)72078-1.

Sheldon, I. M., G. S. Lewis, S. LeBlanc, and R. O. Gilbert. 2006 Defining postpartum uterine disease in cattle. Theriogenology 65:1516-1530. https://doi.org/10.1016/j.theriogenology.2005.08 .021 .

Sordillo, L. M. 2016. Nutritional strategies to optimize dairy cattle immunity. J. Dairy Sci. 99:4967-4982. https://doi.org/10.3168/jds .2015-10354.

Soriani, N., E. Trevisi, and L. Calamari. 2012. Relationships between rumination time, metabolic conditions, and health status in dairy cows during the transition period. J. Anim. Sci. 90:4544-4554. https://doi.org/10.2527/jas.2012-5064.

Suriyasathaporn, W., A. J. J. M. Daemen, E. N. NoordhuizenStassen, S. J. Dieleman, M. Nielen, and Y. H. Schukken. 1999. $\beta$-hydroxybutyrate levels in peripheral blood and ketone bodies supplemented in culture media affect the in vitro chemotaxis of bovine leukocytes. Vet. Immunol. Immunopathol. 68:177-186. https: //doi.org/10.1016/S0165-2427(99)00017-3.

Targowski, S. P., and W. Klucinski. 1983. Reduction in mitogenic response of bovine lymphocytes by ketone bodies. Am. J. Vet. Res. 44:828-830

Trevisi, E., M. Amadori, S. Cogrossi, E. Razzuoli, and G. Bertoni. 2012. Metabolic stress and inflammatory response in high-yielding, periparturient dairy cows. Res. Vet. Sci. 93:695-704. https://doi .org/10.1016/j.rvsc.2011.11.008.

Trevisi, E., N. Jahan, G. Bertoni, A. Ferrari, and A. Minuti. 2015. Pro-inflammatory cytokine profile in dairy cows: consequences for new lactation. Ital. J. Anim. Sci. 14:285-292. https://doi.org/10 .4081/ijas.2015.3862.

Trevisi, E., F. Riva, J. F. S. Filipe, M. Massara, A. Minuti, P. Bani, and M. Amadori. 2018. Innate immune responses to metabolic stress can be detected in rumen fluids. Res. Vet. Sci. 117:65-73. https://doi.org/10.1016/j.rvsc.2017.11.008.

Waite, K. J., Z. E. Floyd, P. Arbour-Reily, and J. M. Stephens. 2001. Interferon-gamma-induced regulation of peroxisome proliferatoractivated receptor gamma and STATs in adipocytes. J. Biol. Chem. 276:7062-7068. https://doi.org/10.1074/jbc.M007894200.

Wang, X., X. Li, C. Zhao, P. Hu, H. Chen, Z. Liu, G. Liu, and Z Wang. 2012. Correlation between composition of the bacterial community and concentration of volatile fatty acids in the rumen during the transition period and ketosis in dairy cows. Appl. Environ. Microbiol. 78:2386-2392. https://doi.org/10.1128/AEM $.07545-11$.

Youssef, M., and M. El-Ashker. 2017. Significance of insulin resistance and oxidative stress in dairy cattle with subclinical ketosis during the transition period. Trop. Anim. Health Prod. 49:239-244. https: //doi.org/10.1007/s11250-016-1211-6.

Zhang, G., D. Hailemariam, E. Dervishi, S. A. Goldansaz, Q. Deng, S. M. Dunn, and B. N. Ametaj. 2016. Dairy cows affected by ketosis show alterations in innate immunity and lipid and carbohydrate metabolism during the dry off period and postpartum. Res. Vet. Sci. 107:246-256. https://doi.org/10.1016/j.rvsc.2016.06.012.

Zoccali, C., R. Maio, G. Tripepi, F. Mallamaci, and F. Perticone. 2006. Inflammation as a mediator of the link between mild to moderate renal insufficiency and endothelial dysfunction in essential hypertension. J. Am. Soc. Nephrol. 17:S64-S68. 